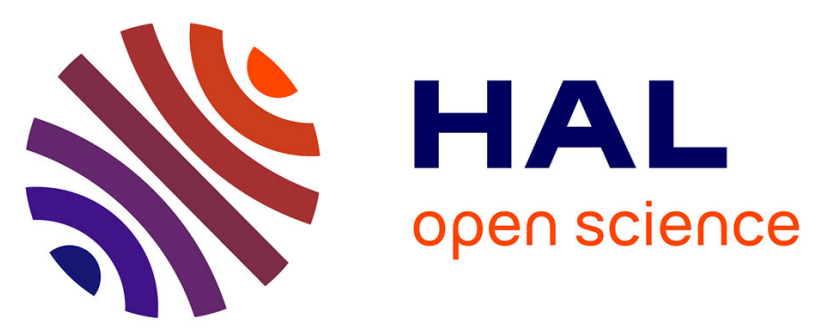

\title{
Contrasting temporal variation in habitat complexity and species abundance distributions in four kelp forest strata
}

Jean-Charles Leclerc, Pascal Riera, Laurent Lévêque, Dominique Davoult

\section{- To cite this version:}

Jean-Charles Leclerc, Pascal Riera, Laurent Lévêque, Dominique Davoult. Contrasting temporal variation in habitat complexity and species abundance distributions in four kelp forest strata. Hydrobiologia, 2016, 777 (1), pp.33-54. 10.1007/s10750-016-2742-6 . hal-01302482

\section{HAL Id: hal-01302482 https: / hal.sorbonne-universite.fr/hal-01302482}

Submitted on 14 Apr 2016

HAL is a multi-disciplinary open access archive for the deposit and dissemination of scientific research documents, whether they are published or not. The documents may come from teaching and research institutions in France or abroad, or from public or private research centers.
L'archive ouverte pluridisciplinaire HAL, est destinée au dépôt et à la diffusion de documents scientifiques de niveau recherche, publiés ou non, émanant des établissements d'enseignement et de recherche français ou étrangers, des laboratoires publics ou privés. 


\section{Contrasting temporal variation in habitat complexity and species abundance distributions in four kelp forest strata}

Jean-Charles Leclerc $1, \stackrel{*}{, 2,3,4}$

Emailleclercjc@gmail.com

Pascal Riera 1,2

Laurent Lévêque 1,5

Dominique Davoult 1,2

1 Sorbonne Universités, UPMC, Univ Paris 06, Station Biologique de Roscoff, Place Georges Teissier, 29680 Roscoff, France

2 CNRS UMR 7144 AD2 M, Station Biologique de Roscoff, Place Georges Teissier, 29680 Roscoff, France

3 Departamento de Ecología, Facultad de Ciencias, Universidad Católica de la Santísima Concepción, Casilla 297, Concepción, Chile

4 Centro de Investigación en Biodiversidad y Ambientes Sustentables (CIBAS), Universidad Católica de la Santísima

Concepción, Concepción, Chile

5 CNRS FR 2424, Station Biologique de Roscoff, Place Georges Teissier, Roscoff, 29680 France

\section{Abstract}

In aquatic environments, habitat complexity influences community species composition at a local scale by partitioning physical niches, mediating water motion and retaining organic matter. Stratified into several microhabitats, kelp forests represent one of the most complex biotopes in coastal waters. These microhabitats are generally made of biogenic structures characterised by species-specific life cycles and their complexity 
is expected to change over time. In a Laminaria hyperborea forest near Roscoff (Brittany, France), we tested whether temporal changes differed among strata (lamina, stipe, holdfast and rock) in terms of habitat complexity, richness and species abundance distributions. At the scale of the study, the epiphytic habitat was relatively stable over four sampling dates, whereas epilithic structures of the understorey appeared particularly unstable in terms of habitat size and distribution among morpho-functional groups of habitat-formers. Unlike sessile species, mobile fauna experienced substantial temporal changes in richness and abundance distribution in all microhabitats studied. Although mobile fauna distribution varies in part with habitat complexity, additional factors likely come into play such as seasonal and stochastic variation in direct and indirect food resources.

\section{Keywords}

Biodiversity

Microhabitats

Biomass

Kelp

\section{Laminaria hyperborea}

Sediments

Seasonality

\section{Electronic supplementary material}

The online version of this article (doi:10.1007/s10750-016-2742-6) contains supplementary material, which is available to authorized users.

Handling editor: Katya E. Kovalenko

\section{Introduction}

In natural communities, habitat features may affect the distribution of species diversity and abundance (MacArthur \& MacArthur, 1961; McGuinness \& Underwood, 1986; Downes et al., 1998; Tokeshi \& Arakaki, 2012). At local scales, habitat complexity is characterised by different traits of physical structure: the diversity, the spatial arrangement, the size and the density of structural elements (Tokeshi \& Arakaki, 2012); e.g. pits and grooves on hard substrata (McGuinness \& Underwood, 1986). In aquatic ecosystems (see Kovalenko et al., 2012 for review), habitat complexity is thought to protect 
organisms from environmental stresses, including physical forces (e.g. water motions), and mediate biological interactions (e.g. predation pressure). Furthermore, habitat complexity is expected to enhance retention of particulate food materials, which represent the main trophic resource for benthic communities, generally dominated by particle-feeders (Miller and Page, 2012). This leads to numerous positive interactions in associated communities, generally favouring species diversity, numerical abundances, biomass, rates of propagule retention, settlement and survivorship (Altieri \& Van de Koppel, 2014), therefore influencing all aspects of "species abundance distributions" (sensu Morlon et al., 2009).

AQ1

At local scale, rocky reef complexity results from both abiotic and biogenic structures, which exhibit contrasting temporal dynamics. Abiotic structures are composed of diverse kinds of rock and interstitial sediments, whose features affect species abundance distributions (Littler \& Littler, 1984; McGuinness \& Underwood, 1986; Hily \& Jean, 1997; Airoldi, 2003 ). Although bedrock is quite stable through time, its structure, hardness and integrity can vary spatially and temporally depending on its nature (e.g. Azzarello et al., 2014), some boulders move and are overturned due to water motion and human activities (Littler \& Littler, 1984; Chapman \& Underwood, 1996; Arzel, 1998), and the amounts of sediment can vary according to stochastic deposits (Littler et al., 1983; Gibbons, 1988; McQuaid \& Dower, 1990; Airoldi, 2003 ), which in turn can affect benthic communities. Hard substrata support several biogenic structures which, unlike abiotic structures, may fluctuate according to the differential turn-over of engineer-organisms (Bruno \& Bertness, 2001). Such biogenic structures consist both of animal concretions including corals, mussels, bryozoans, ascidians, sponges and tube worms (McCormick, 1994; Dubois et al., 2002; Castilla et al., 2004; Buschbaum et al., 2009; Kovalenko et al., 2012), and of diverse assemblages of epilithic and epiphytic seaweeds (Hacker \& Steneck, 1990; Martin-Smith, 1993; Norderhaug, 2004; Wulff, 2006; Christie et al., 2007). Although the chemical composition of seaweeds (nutritional value, secondary metabolites) may influence their utilisation by fauna as trophic resource and in turn as habitat (Wulff, 2006; Paul et al., 2011; Tokeshi \& Arakaki, 2012), their physical features, such as shape and roughness, are generally more critical (Hacker \& Steneck, 1990; Norderhaug, 2004; Christie et al., 2007; Schaal et al., in press). In kelp forests that dominate temperate reefs in shallow waters, perennial species form a large canopy assumed to protect the understorey 
components from hydrodynamic disturbances and influence light intensity and wavelength, therefore providing a range of stratified habitats for a high diversity of understorey and epiphytic seaweeds, as well as many sessile invertebrates (Norton et al., 1977; Graham, 2004; Cárdenas et al., 2015). All these habitat-formers have distinct life cycles and may vary throughout the year according to growth and senescence processes (Whittick, 1983; MartinSmith, 1993 ; Prathep et al., 2003). Consequently, the kelp forest habitat is one of the most complex biotopes in coastal marine ecosystems.

In Europe, subtidal kelp forests are dominated by Laminaria hyperborea, (Gunnerus) Foslie a species encountered at depth up to about $30 \mathrm{~m}$ (Kain, 1971). Kelp individuals may live for about 20 years (Kain, 1963; Rinde \& Sjøtun, 2005), can reach up to $3.5 \mathrm{~m}$ in length and are considered as a habitat of their own composed of three stratified parts (Fig. 1 a): the holdfast, the stipe and the lamina (Kain, 1963 ). Macroalgal and faunal epiphytes develop all along the entire thallus, making up a high amount of biomass mainly concentrated along the stipe (Whittick, 1983). Owing to different morphological features (Fig. 1 a), these microhabitats shelter specific assemblages of mobile fauna at local scale (Schultze et al., 1990; Christie et al., 2003 ). At broader spatial scales, stipe assemblages have been shown to be driven by the interplay between hydrodynamic conditions, the relative proportion of morphological types (e.g. smooth, rough and bushy) of epiphytic seaweeds and their total amount, i.e. habitat size (Christie et al., 2007; Norderhaug et al., 2007, 2014). The perennial holdfasts, in spite of relatively few epiphytic seaweeds, generally shelter the greatest diversity of sessile and mobile fauna associated with kelp plants (Jones, 1973; Moore, 1973 ). Each winter, a new ring of haptera (holdfast fixation structure) forms at the top of the holdfast and grows in length until it reaches the rock surface (Kain, 1963). These growth patterns enhance, besides epiphytic turn-over, complexity of the holdfast microhabitat. Also during the winter, the stipe expands in width and length, which - albeit without any change in stipe complexity - increases the surface area available to epiphyte colonisation (Kain, 1982). The flat and smooth lamina is shed in early spring (pattern visible in Fig. 1 b) and totally renewed thereafter (Kain, 1976a; Lůning, 1986 ). In L. hyperborea forests, habitat complexity and communities associated with the diverse understorey seaweeds (Norton et al., 1977) remain largely understudied. Both epilithic and epiphytic assemblages are composed of perennial, pseudo-perennial and annual seaweeds which are utilised by a wide range of fouling and mobile invertebrates (Seed \& O'Connor, 1981; 
Dean \& Connell, 1987a; Martin-Smith, 1993). As such, kelp forest strata may experience different temporal variations in complexity, and in turn influence patterns in faunal diversity, composition and abundance over the year.

Fig. 1 From e.proofing layout, all figures appear in a poor quality... If it is suppose to be the final apperance, I can easily provide you revised versions of all these figures if the ones I sent were not suitable. Just in case I re-uploaded the same, but in PNG version. Please do not hesitate to contact me regarding this issue.

a Schematic illustrating the typical stratification and sessile biota associated with Laminaria hyperborea. Morpho-functional groups of seaweeds (( 1$)$ crustose, (2) smooth leaf-like, (3) rough leaf-like and (4) bushy) and sessile fauna ((5) thin sheets, (6) cushions, (7) massive and (8) branching forms) considered in this study are indicated. b Underwater sampling of the rocky substratum $\left(0.1 \mathrm{~m}^{2}\right.$ quadrat $)$ using a trowel and an air pump ( $\left.\sim 2 \mathrm{~m} \mathrm{high}\right)$ connected to a 1-mm-mesh collector. Roscoff study site around low tide, March 2013. Courtesy of Wilfried Thomas, SBR
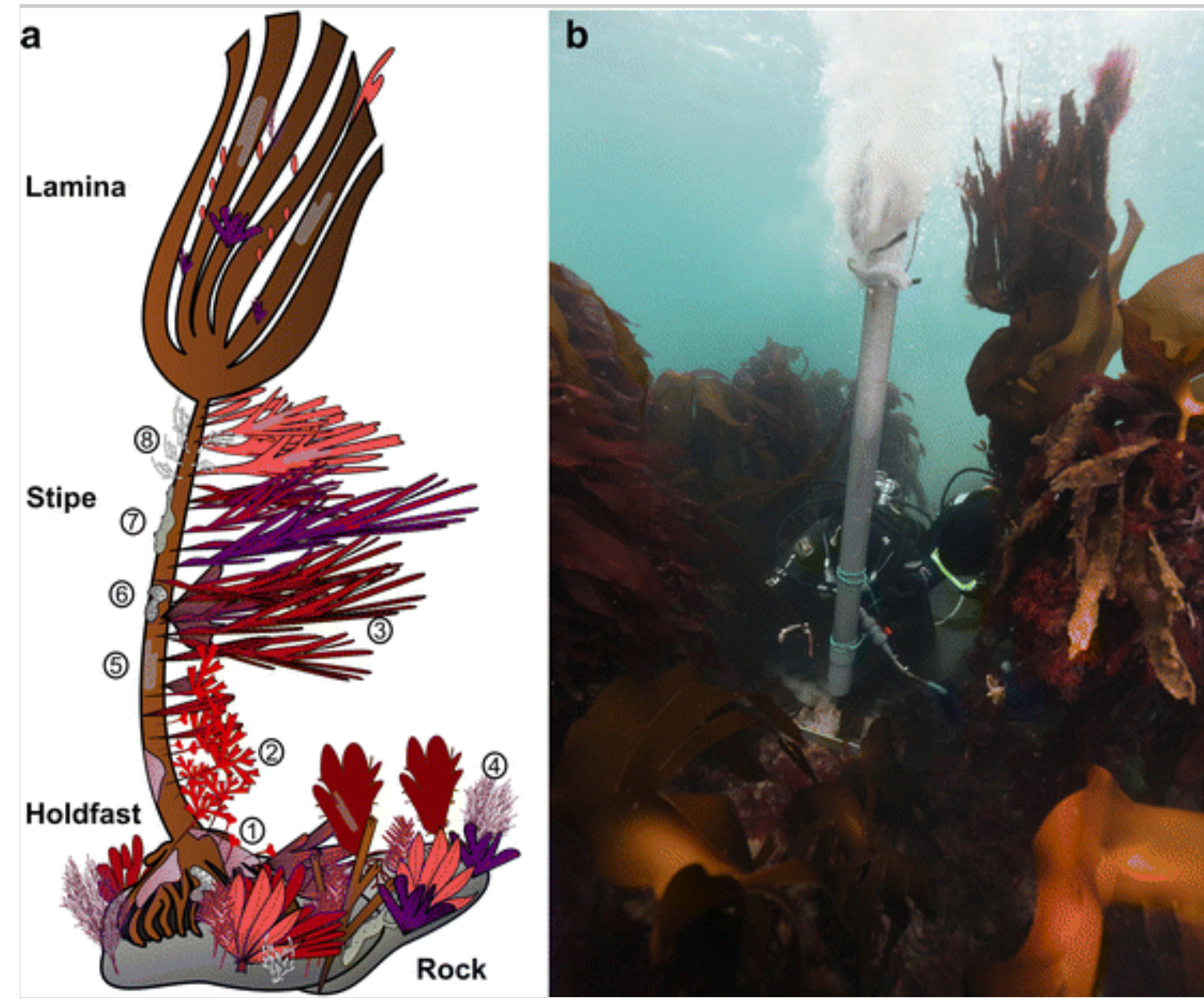

In the present study, we analysed the diversity and the biomass abundance distributions of macroalgal and macrofaunal species across the four strata of 
Laminaria hyperborea forest in Roscoff (Brittany, France), at four dates over the 2010-2011 period. From these data, we tested whether temporal patterns in habitat features differed among the kelp forest strata and whether these patterns could be related to specific morpho-functional groups of seaweeds and sessile fauna, or particular species. In that case, we hypothesised that temporal patterns in habitat features would explain, at least partly, those of mobile fauna, in terms of both richness and abundance distributions within each stratum.

\section{Materials and methods}

\section{Study site}

The study site was located near Roscoff $\left(48^{\circ} 43.556^{\prime} \mathrm{N}, 4^{\circ} 01.415^{\prime} \mathrm{W}\right.$, France), situated $1 \mathrm{~km}$ from the shore and $2.5 \mathrm{~m}$ below chart datum (Leclerc et al., 2013 ). The bedrock is littered with boulders and coarse interstitial sediment.

The site is moderately exposed to wave action (facing west) and to tidal currents (maximal tidal range: $9 \mathrm{~m}$ ) and the water mass is well mixed throughout the year (Birrien et al., 1991). In addition to diurnal and seasonal oscillations, the incident light reaching the canopy varies with tidal cycles, with maximum irradiances occurring around noon during low spring tides (Appendix A-Supplementary material 1). At this depth, the kelp forest $\left(\approx 1 \mathrm{~km}^{2}\right)$ is largely dominated by L. hyperborea, although a few Saccorhiza polyschides (Lightfoot) Batters, Cystoseira baccata (S. G. Gmelin) P. C. Silva and Halidrys siliquosa (L.) Lyngbye patchily colonise light gaps (see also diver observations in Appendix B-Supplementary material 2). In autumn 2010, kelp densities were measured within $0.25 \mathrm{~m}^{2}$ three-sided (horseshoeshaped) quadrats $(n=60)$ for three stipe-length classes: $0-10,10-40,>40 \mathrm{~cm}$. Densities were estimated at $16.9 \pm 11.4$ individuals $\mathrm{m}^{-2}$ (mean $\pm \mathrm{SD}$ ), largely dominated by canopy plants (stipe $>40 \mathrm{~cm}, 13.1 \pm 6.6$ ind. $\mathrm{m}^{-2}$ ), with densities of other kelps [S. polyschides and Laminaria digitata (Hudson) J. V. Lamouroux] estimated at $0.1 \pm 0.7$ individuals $\mathrm{m}^{-2}$. The nearby environment is characterised by mosaic habitats (Joubin, 1909), with numerous rocky islands surrounded by infralittoral coarse sand/gravel flats and fine sand beaches.

Zostera marina L. beds are well developed on soft substrata of the infralittoral fringe. Rocky substrata are dominated by Fucales on intertidal levels, by L. digitata on infralittoral fringe and by L. hyperborea at deeper depths (up to ca. $15 \mathrm{~m}$, pers. obs.). From diver observations and information provided by local fishermen, the study site was considered to be preserved from kelp-harvesting, but was frequently exploited for abalones and large 
decapods.

\section{Sampling}

Sampling was performed by scuba divers within a central plot (diameter of ca. $5 \mathrm{~m}$ ) in mid-November 2010, late March 2011, late June 2011 and mid-September 2011. At each sampling occasion, five L. hyperborea adults were collected in 1-mm-mesh bags (Christie et al., 2003). A substantial part of the within-site variability in the biotic colonisation of kelp-associated biota can be explained by age and size (Whittick, 1983; Anderson et al., 2005) and population samples $(n \geq 30)$ at each date would have been needed to infer temporal patterns undergone within the whole kelp forest. In order to avoid massive sampling within this pristine area, that could have altered the environment from one date to another, only large adult kelp were selected underwater according to their total length (1-2 m) before further biometric analyses in the laboratory. As such, our results are to be interpreted with caution as they reflect temporal changes within a subset-though relevant as canopy individuals are highly colonised by epiphytes (Christie et al., 1998 ) — of the kelp forest. Individual kelp were enclosed in a bag and cut off at their base to collect the stipe and its adjoining lamina. The holdfast was then pried away from the rock using a trowel and collected in a separate bag. The surrounding substratum (apparent rock on horizontal surfaces) was sampled within five $0.1 \mathrm{~m}^{2}$ quadrats. Both sessile and mobile species were scratched from the rocky substratum using a trowel and directly sucked up using an air-regulated pump connected to a 1-mm-mesh collector (Fig. 1 b).

In the laboratory, each bag was carefully rinsed with seawater over a $500-\mu \mathrm{m}$ sieve. Bag contents were fixed in their entirety in a buffered formaldehyde solution (3\%) and containers were kept in the dark to limit fading of macroalgal specimens. Formaldehyde limited the secretion of alginic acids by kelp and facilitated processing. Sessile species were separated from their substratum (i.e. epilithic and epiphytic seaweeds on stipes, laminae, dissected holdfasts) using a scalpel under a dissecting microscope before further species-specific biomass determination. Although the stipe and its adjoining lamina were collected in the same bag, these two strata were treated separately for sessile fauna and seaweed abundances. Few mobile species inhabit laminae (Norton et al., 1977; Christie et al., 2003 ); therefore most mobile species (except Patella pellucida L. associated with lamina) found in the stipe/lamina samples were assumed to inhabit stipe epiphytes. Fauna and flora were sorted according to origin (stipe/lamina, holdfast or rock substratum) 
and their ash-free dry mass (AFDM, Crisp, 1984) determined at the species level whenever possible (see "Results" section and Appendices

B-D-Supplementary materials 2-4). In addition, mobile fauna were counted to quantify numerical abundances.

To allow temporal comparisons of communities associated with kelp strata, each kelp sample was processed for a series of biometric measurements (age, size and volume). These parameters were compared among sampling dates using analyses of variance (ANOVAs), followed, when appropriate, by Student-Newman-Keuls (SNK) post hoc tests. No data transformation was required for these analyses given the homoscedasticity in the data (verified using Levene's test). Age was estimated from growth marks in the holdfast, using the method described in Kain (1963). Each holdfast was packed in a thin plastic bag and placed in a transparent water jar to measure its total displacement volume. Holdfast interstitial volume, 'ecospace' following Jones (1971), was determined by the difference between total and dissected holdfast volumes, measured in a graduated tube after fauna sorting. Owing to the unique morphology and growth patterns of L. hyperborea fronds (Kain, 1976a), laminae were only assessed for their total biomass (ash-free dry mass).

\section{Data analyses}

Comparisons of univariate and multivariate patterns were performed separately for the kelp and the rock substratum. Unlike rock samples $\left(0.1 \mathrm{~m}_{2}^{2}\right)$, kelp holdfasts covered variable surfaces (ranging from 0.01 to $0.03 \mathrm{~m}^{2}$ ). However, both kelp plants and kelp strata (lamina, stipe and holdfast) can be considered as sampling units provided that a covariate (e.g. kelp age, holdfast volume, stipe surface area) is taken into consideration as rough estimator of the actual sampling size (Anderson et al., 2005; Norderhaug et al., 2014). If all kelp strata are to be included in the same quantitative analysis (disregarding their 3D structure), a common covariate is needed (i.e. total kelp size or age).

\section{Habitat complexity}

According to the biometric analyses (see "Results" section), the habitat complexity due to sampled kelp plants on their own was considered constant over time. The same assumption was made regarding the rock substratum.

In the present study, we focused specifically on the habitat created by sessile taxa (seaweeds and fauna) inhabiting these substrata. Habitat complexity was 
estimated considering two parameters (Tokeshi \& Arakaki, 2012): (1) habitat size and (2) relative abundance of structural elements. Habitat size is generally viewed as the amount of living space (i.e. surface area) that can be estimated by several indicators, including the total volume or the biomass of all structural elements (Christie et al., 2009; Kovalenko et al., 2012; Norderhaug et al., 2014), whose relative abundances can be given either by density, cover, volume and biomass (Kelaher, 2002; Thrush et al., 2011; Norderhaug et al., 2014 ). Recently, Norderhaug et al. (2014) successfully related the diversity $\left(S, H^{\prime}\right)$ and community structure of associated fauna to the fresh biomass of different morpho-functional categories of epiphytic fleshy seaweeds. In order to account for variability in relative density due to body composition and concentration in inorganic salts and minerals (Murray et al., 2006), we used AFDM of either epiphytic or epilithic seaweeds (fleshy and calcareous) and sessile fauna to estimate the habitat size. According to their morphological features indicative of different surface areas at comparable volume occupancy (see also Fig. 1 a), sessile taxa were assigned to one of the four morphofunctional seaweed classes (crustose, smooth leaf-like, rough leaf-like and bushy, Christie et al., 2007; Norderhaug et al., 2014) and four classes of fauna (thin sheets, cushions, massive and branching forms, Greene \& Schoener, 1982; Bell et al., 2006). The distribution among structural elements was then given by the biomass (AFDM) distribution among these morpho-functional groups of sessile taxa.

On kelp plants, temporal changes in biomass distribution among structural elements were examined with a three-way design using permutational multivariate analysis of variance (PERMANOVA, Anderson, 2001). Factors were strata (fixed, three levels: lamina, stipe, holdfast), date (random, crossed with strata, four levels), kelp-individual (random, nested within date) and age (years), included as a covariate. Permutations were based on a Bray-Curtis similarity matrix (Clarke \& Warwick, 2001). This matrix was generated from square-root-transformed biomass, including a dummy variable (corresponding to the square-root-transformed minimal accuracy in biomass measurements, i.e. $0.1 \mathrm{mg}$ ) to calculate similarity among non-colonised samples (Clarke et al., 2006), such as newly formed laminae observed in spring. PERMANOVA was performed using 4999 permutations of residuals under a reduced model and significance was accepted at $P<0.05$. On the rock substratum, a one-way design (date, four levels) was used and the unrestricted permutation method was chosen. As for kelp, 4999 permutations were based on a Bray-Curtis similarity matrix generated from square-root-transformed data. Temporal 
changes in habitat size (total sessile taxa biomass) were examined with PERMANOVAs using the same models described above for kelp strata and the rock substratum, respectively. These univariate PERMANOVAs were based on a Euclidean distance matrix generated from untransformed biomass data, which is analogous to ANOVA.

When appropriate, all tests were followed by pairwise comparisons among consecutive sampling dates and the respective contributions of morphofunctional groups to observed dissimilarities were estimated using similarity percentage (SIMPER) analyses (Clarke \& Warwick, 2001).

\section{Species abundance distributions}

Seaweeds, sessile and mobile fauna were analysed separately for species richness and abundance distributions. Temporal changes in species richness were examined with univariate PERMANOVAs (based on a Euclidean distance matrix generated from untransformed data) using the models described above for kelp strata and the rock substratum, respectively, followed by pairwise comparisons among sampling dates, when appropriate.

The biomass distributions of seaweed and sessile fauna species were analysed using multivariate PERMANOVAs with the models described above for kelp strata and the rock substratum, respectively. Prior to analysis, least common species (found in less than $5 \%$ of samples) were removed. Combined with PERMANOVAs, samples were ordinated using non-metric multidimensional scaling (nMDS). Ordinations and permutations were computed on a Bray-Curtis similarity matrix generated from square-root-transformed data (+dummy variable). Mobile fauna abundance distributions were analysed according to both square-root-transformed biomass and numerical abundance data, using the models described above. Owing to the inability to assign mobile species to stipe or adjoining lamina (sampled in the same bag), these strata were considered as one, therefore the random factor 'strata' was reduced to two levels: stipe/lamina and holdfast. When significant differences between two consecutive sampling dates were detected (pairwise comparisons), species contributions to observed dissimilarities were estimated using SIMPER analyses (Clarke \& Warwick, 2001). Only abundant species found in the first $50 \%$ of cumulated pairwise dissimilarities $\left({ }^{-} j \%\right.$ ), for ratio ${ }^{-} j \mathrm{SD}>1$ (Clarke $\&$ Warwick, 2001) in at least one pairwise comparison, were considered relevant to be explored among sampling dates.

Linking variations in mobile fauna distribution with habitat 


\section{complexity}

Finally, we explored to what extent temporal changes in mobile fauna richness and abundance distribution were explained by modifications in habitat complexity in three kelp forest strata. For stipe/lamina, holdfast and the rock substratum, matrices generated from mobile fauna richness (Euclidean distance) and abundance distributions (Bray-Curtis dissimilarity) were compared to matrices generated from habitat size and biomass distribution among morpho-functional groups using the RELATE procedure (Clarke \& Ainsworth, 1993; Clarke \& Warwick, 2001). For each pairwise comparison, a Spearman's rank correlation coefficient $(\rho)$ between matrices was tested for significance using 4999 permutations. In addition, a one-way design including a covariate was used for stipe/lamina, holdfast and the rock substratum. The main factor was date (random); habitat size was included as a covariate, using PERMANOVAs based on mobile fauna richness and abundance distribution matrices. Particular attention was given to significant interactions between habitat size (the covariate) and date (the main factor), which could indicate that, in addition to habitat size, temporal patterns in mobile fauna distribution involve additional processes.

For all analyses, the homogeneity in multivariate dispersion among sampling periods was checked using the PERMDISP test (Anderson et al., 2008). Run in tandem for community analyses and supported by ordination methods, PERMANOVA and PERMDISP can help distinguish between "location" (change in abundance distribution) and "dispersion" (change in heterogeneity among replicates) effects (Anderson et al., 2008). Based on a Euclidean distance matrix for univariate metrics (richness, habitat size), the PERMDISP test is equivalent to the traditional Levene's test. All analyses were performed using PRIMER 6 with the PERMANOVA add-on (Clarke \& Warwick, 2001 ; Anderson et al., 2008).

\section{Results}

During the survey, a total of 100 macroalgal taxa and 387 macrofaunal taxa (106 sessile, 281 mobile) were identified from samples and in situ observations (species lists and authorities are given in Appendices B-D-Suppplementary material 2-4).

\section{Temporal variability in biogenic habitat provided by kelp}

The habitat complexity due to sampled kelp plants was relatively constant 
over time, disregarding lamina turn-over. Kelp age did not differ among sampling dates (ANOVA, $F_{3,16}=0.396, P=0.757$ ), ranging from 4 to 10 years $(6.2 \pm 1.6$ years, $S D)$. Neither stipe length $(85.5 \pm 15.1 \mathrm{~cm})$, mean diameter $(2.3 \pm 0.2 \mathrm{~cm})$, nor surface area $\left(622.3 \pm 132.1 \mathrm{~cm}^{2}\right)$ differed significantly among sampling periods (ANOVAs, $P \geq 0.05$ ). Neither holdfast total $(568.7 \pm 240.3)$ nor interstitial $(402.7 \pm 194.0 \mathrm{ml})$ volumes differed among sampling dates (ANOVAs, $P>0.80$ ). Lamina biomass (standardised with stipe biomass) decreased marginally from November to March (SNK, $P=0.056)$, the period during which the old lamina decays and a new lamina grows actively $\left(F_{3,16}=9.48, P<0.001\right.$, SNK: Nov. $=$ Mar. $<$ Jun. $<$ Sep. $)$, as reflected by the reduction in $\%$ ash $\left(F_{3,16}=13.07, P<0.001\right.$, SNK:

Nov. $>$ Mar. $=$ Jun. $<$ Sep.).

\section{Habitat complexity}

On kelp plants, temporal patterns in habitat complexity, as previously defined by habitat size and biomass distribution among morpho-functional groups of seaweeds and sessile fauna, varied with the kelp stratum considered (Fig. 2, interaction terms in Table 1). On laminae, total habitat size was lower than on the other kelp parts and did not vary significantly during the survey but there was a slight change in the distribution among morpho-functional groups (Fig. 2 a). Biomass was dominated by smooth and rough leaf-like seaweeds, abundant on old senescing laminae (when still attached) in March. On the stipe, the biomass distribution among morpho-functional groups did not vary during the year (Fig. 2 b; Table 1). Smooth and rough leaf-like seaweeds dominated, while sessile fauna biomass was mainly represented by thin sheets, cushion-like and massive-form species. Within and on holdfasts, habitat size did not vary over time, but the biomass distribution of morpho-functional groups differed in November compared to the other months (Fig. 2 c; Table 1). Following their senescence, smooth and rough leaf-like seaweeds were less abundant in the fall.

\section{Fig. 2}

Biomass [square-root-transformed mean AFDM $(\mathrm{g}) \pm \mathrm{SD}$ ] of morpho-functional groups of seaweeds and sessile fauna according to stratum (a lamina, b stipe, c holdfast, $\mathbf{d}$ rock) and sampling dates 

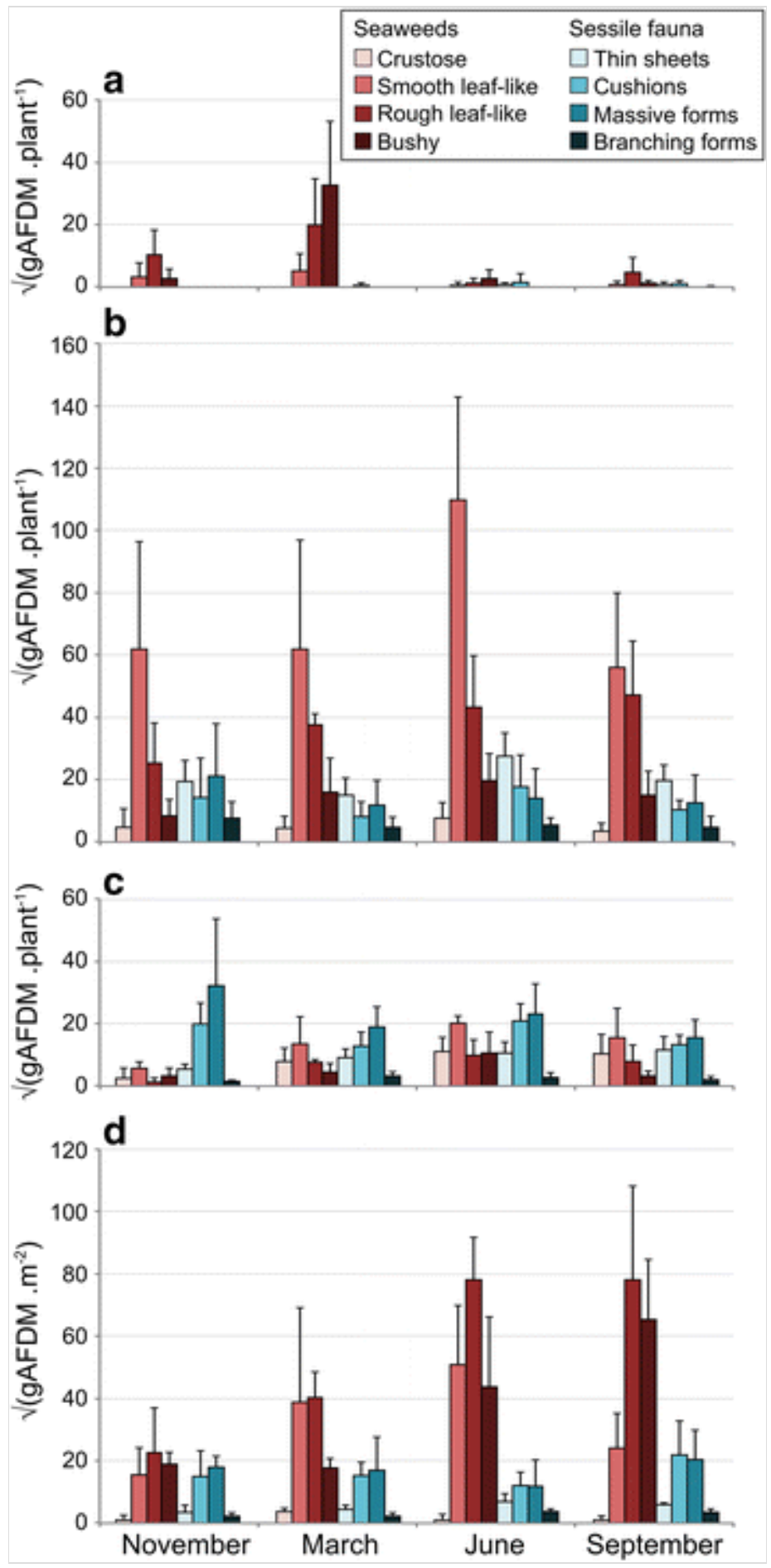

Table 1

Results of PERMANOVA tests for differences in habitat size (total biomass) and biome distribution among morpho-functional groups on kelp and rock

Habitat size: complexity

Total amount (gAFDM)

Morpho groups' biomass distribution

Transformation

None

Square root + dummy

Distance/similarity Euclidean distance

Bray-Curtis similarity 


\section{\begin{tabular}{l|l|l|l|l|l|l} 
df & MS & Pseudo- $F$ & $P$ & MS & Pseudo- $F$ & $P$
\end{tabular}}

Source: kelp

\begin{tabular}{l|l|l|l|l|l|l|l}
\hline Age & 1 & 0.0 & 0.00 & 0.998 & 2473.0 & 2.68 & $\mathbf{0 . 0 3 4}$ \\
\hline Stratum & 2 & 490.9 & 12.76 & $\mathbf{0 . 0 1 0}$ & 35089.0 & 16.09 & $\mathbf{0 . 0 0 1}$ \\
\hline Date & 3 & 47.6 & 3.74 & $\mathbf{0 . 0 1 8}$ & 2461.7 & 3.06 & $<\mathbf{0 . 0 0}$ \\
\hline Kelp (date) & 15 & 12.7 & 0.88 & 0.618 & 804.6 & 1.05 & 0.375 \\
\hline Stratum $\times$ date & 6 & 38.5 & 2.67 & $\mathbf{0 . 0 2 3}$ & 2180.2 & 2.86 & $<\mathbf{0 . 0 0}$ \\
\hline Res. & 32 & 14.4 & & & 763.1 & & \\
\hline PERMDISP & & $\begin{array}{l}F_{3,56}=4.602, \\
P=0.069\end{array}$ & & $\begin{array}{l}F_{3,56}=1.431, \\
P=0.458\end{array}$ & \\
\hline
\end{tabular}

Source: rock

\begin{tabular}{l|l|l|l|l|l|l|l}
\hline Date & 3 & 150.5 & 7.58 & $\mathbf{0 . 0 0 3}$ & 1019.9 & 7.4 & $<0.00$ \\
\hline Res. & 16 & 19.8 & & & 137.8 & & \\
\hline PERMDISP & & $\begin{array}{l}F_{3,16}=5.843, \\
P=\mathbf{0 . 0 3 7}\end{array}$ & & $\begin{array}{l}F_{3,16}=0.093, \\
P=0.977\end{array}$ & \\
\hline & & $\begin{array}{l}\mathrm{N}=\mathrm{M}=\mathrm{J}=\mathrm{S} \\
(>\mathrm{N})\end{array}$ & & \\
\hline
\end{tabular}

Pairwise tests

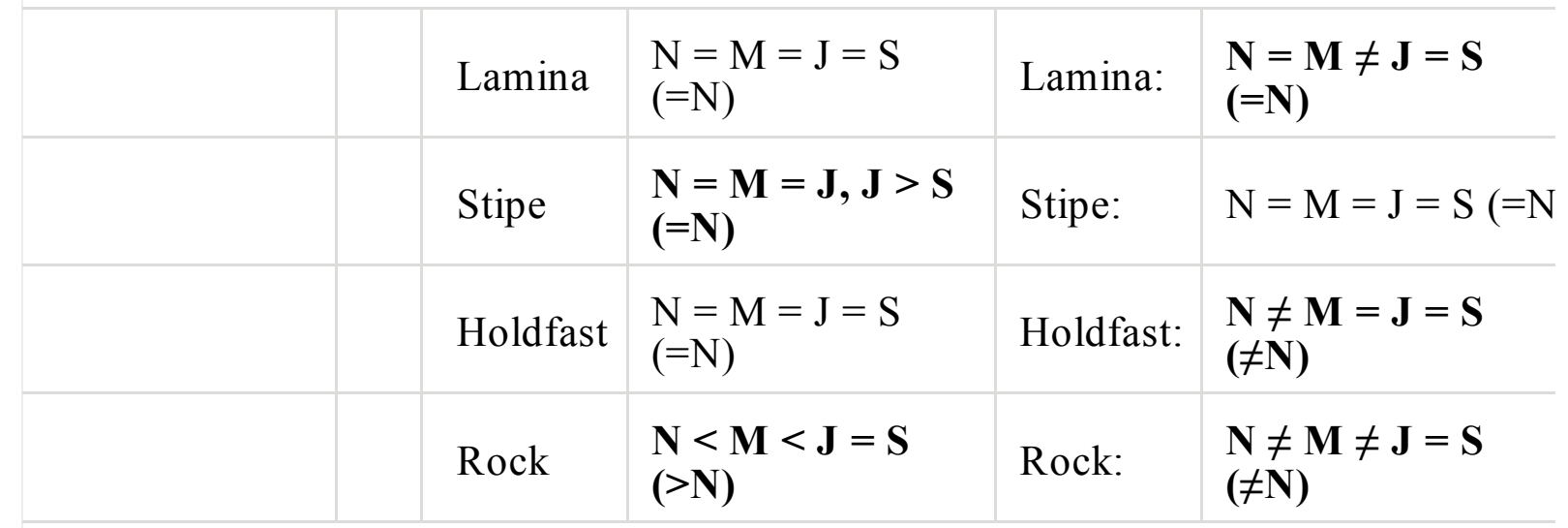

PERMDISP tests for differences in multivariate dispersion around the centroid amon€ sampling dates are presented. Significant $P$ values $(<0.05)$ are in bold. Pairwise tests are summarised ( $N$ November, $M$ March, $J$ June, $S$ September)

AQ2

Unlike kelp, the rock substratum varied greatly in terms of habitat size and distribution among morpho-functional groups (Table 1, pairwise tests), especially seaweeds (Fig. 2d). Habitat size increased from November (1.7 gAFDM. $0.1 \mathrm{~m}^{-2}$ ) to June (13.2 gAFDM. $0.1 \mathrm{~m}^{-2}$ ), mainly due to the growth 
of smooth leaf-like, rough leaf-like, and bushy seaweeds (SIMPER). Crustose algae were likely underestimated due to the sampling protocol (scratching) for this stratum.

\section{Species abundance distributions}

\section{Seaweeds}

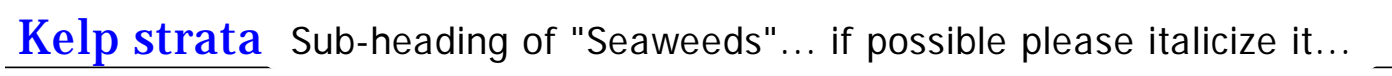

On kelp plants, temporal patterns in both seaweed species richness and biomass distribution varied with the stratum (significant interaction, Table 2). Unlike on laminae and holdfasts, stipes showed no variation in seaweed richness or biomass distribution among sampling periods (Figs. 3a-c, $4 \mathrm{a}$ ). On laminae (Fig. 3 a), 23 macroalgal species in all were encountered, their richness being minimal in June (2.2 $\pm 1.3 \mathrm{SD}$ ), following the complete loss of the senescing lamina in spring. With regard to biomass distribution, the dissimilarity between sampling dates was mainly due to the growth of Hincksia hincksiae and Cryptopleura ramosa on the senescing laminae between November and March, followed and loss after lamina shedding in the spring (SIMPER, Appendix E-Suppplementary material 5). On stipes, a total of 52 seaweed species were identified and the mean richness was $17.2 \pm 4.8$ (Fig. 3 b). Throughout the year, Palmaria palmata, Rhodymenia pseudopalmata, Lomentaria articulata and four Delesseriaceae species were found on all stipe samples and accounted for on average $90 \%$ of the epiphytic biomass (Appendix E-Suppplementary material 5). On holdfasts (Fig. 3 c), 65 seaweed species were encountered during the survey and macroalgal richness increased from November $(S=6)$ to June $(S=23)$, and then decreased ( $S=15$ in September). The biomass distribution of holdfast epiphyte species varied among sampling dates (Fig. 4 a; Table 2), specifically between November and March, and between June and September. The main dissimilarity between November and March was due to the growth of the Corallinales/Peyssonnelia complex, Callophyllis laciniata and Cryptopleura ramosa (Appendix E-Suppplementary material 5). Between June and September, these species lost substantial amount of biomass, contributing along with Polyneura bonnemaisonii, Heterosiphonia plumosa, Rhodophyllis divaricata and Ulva rigida, to the dissimilarity between summer periods. 
Table 2

Results of PERMANOVA tests for differences in species richness (S) and abundance (bio

Seaweeds

Richness S

Species biomass distributio

Transformation

None

Square root + dummy

Distance/similarity Euclidean distance

Bray-Curtis similarity

df MS

Pseudo-F $P$

MS

Pseudo-F $P$

Source: kelp

\begin{tabular}{|l|l|l|l|l|l|l|l|}
\hline Age & 1 & 23.3 & 0.89 & 0.358 & 1207.4 & 1.3 & 0.24 . \\
\hline Stratum & 2 & 1002.5 & 12.09 & $\mathbf{0 . 0 1 1}$ & 33241.0 & 13.6 & $\mathbf{0 . 0 0}$ \\
\hline Date & 3 & 171.3 & 11.28 & 0.001 & 3331.7 & 4.4 & 0.00( \\
\hline Kelp (date) & 15 & 15.2 & 1.44 & 0.191 & 756.8 & 1.1 & $0.25 \vdots$ \\
\hline Stratum $\times$ date & 6 & 82.9 & 7.86 & $<\mathbf{0 . 0 0 1}$ & 2445.0 & 3.5 & $<\mathbf{0 . 0}$ \\
\hline Res. & 32 & 10.6 & & & 692.1 & & \\
\hline PERMDISP & & $F_{3,56}=15.664, P=\mathbf{0 . 0 0 2}$ & $\begin{array}{l}F_{3,56}=2.495, \\
P=0.092\end{array}$ & \\
\hline
\end{tabular}

Source: rock

\begin{tabular}{|c|c|c|c|c|c|c|c|}
\hline Date & 3 & 450.7 & 38.0 & $<0.001$ & 3784.7 & 3.8 & $<\mathbf{0 . 0}$ \\
\hline Res. & 16 & 11.9 & & & 1006.9 & & \\
\hline PERMDISP & & \multicolumn{2}{|c|}{$\begin{array}{l}F_{3,16}=0.812 \\
P=0.561\end{array}$} & & \multicolumn{3}{|c|}{$\begin{array}{l}F_{3,16}=3.813 \\
P=0.068\end{array}$} \\
\hline
\end{tabular}

Pairwise tests

\begin{tabular}{l|l|l|l} 
Lamina: & $\begin{array}{l}\mathbf{N}=\mathbf{M}>\mathbf{J}=\mathbf{S} \\
(=\mathbf{N})\end{array}$ & Lamina: & $\begin{array}{l}\mathbf{N} \neq \mathbf{M} \neq \mathbf{J} \neq \mathbf{S} \\
(=\mathbf{N})\end{array}$ \\
\hline Stipe: & $\mathbf{N}=\mathbf{M}=\mathbf{J}=\mathrm{S}(=\mathrm{N})$ & Stipe: & $\mathbf{N}=\mathbf{M}=\mathbf{J}=\mathrm{S}(=$. \\
\hline Holdfast: & $\begin{array}{l}\mathbf{N}<\mathbf{M}<\mathbf{J}>\mathbf{S} \\
(>\mathbf{N})\end{array}$ & Holdfast: & $\begin{array}{l}\mathbf{N} \neq \mathbf{M}=\mathbf{J} \neq \mathbf{S} \\
(\neq \mathbf{N})\end{array}$ \\
\hline Rock: & $\begin{array}{l}\mathbf{N}<\mathbf{M}=\mathbf{J}>\mathbf{S} \\
(>\mathbf{N})\end{array}$ & Rock: & $\begin{array}{l}\mathbf{N} \neq \mathbf{M} \neq \mathbf{J}=\mathbf{S} \\
(\neq \mathbf{N})\end{array}$
\end{tabular}

PERMDISP tests for differences in multivariate dispersion around the centroid amon bold. Pairwise tests are summarised ( $N$ November, $M$ March, $J$ June, $S$ September) 
Fig. 3

Macroalgal and macrofauna species (sessile and mobile taxa) richness (mean $\pm \mathrm{SD}$ ) according to stratum (a lamina, b stipe, $\mathbf{c}$ holdfast, $\mathbf{d}$ rock) and sampling dates. No data for mobile fauna on laminae. Circles indicate cumulative species richness calculated for all samples combined
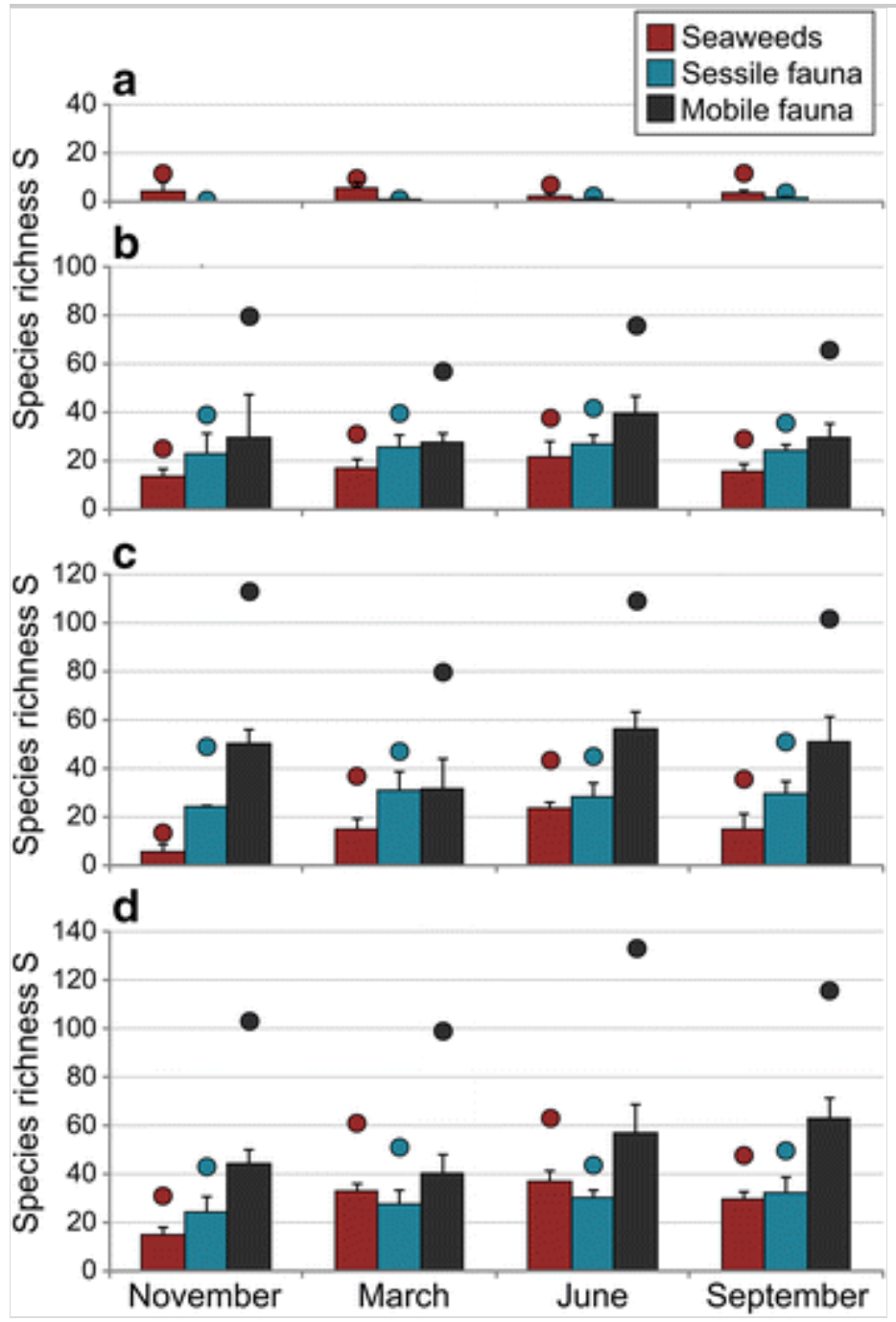

\section{Fig. 4}

Non-metric multidimensional scaling (nMDS) performed from a Bray-Curtis similarity matrix generated from square-root-transformed abundance data: biomass (+dummy variable) of seaweeds (a, $\left.\mathbf{a}^{\prime}\right)$, sessile fauna $\left(\mathbf{b}, \mathbf{b}^{\prime}\right)$ and mobile fauna $\left(\mathbf{c}, \mathbf{c}^{\prime}\right)$, or numerical abundance of mobile fauna $\left(\mathbf{d}, \mathbf{d}^{\prime}\right)$ in kelp (left panels) and rock samples (right panels) 

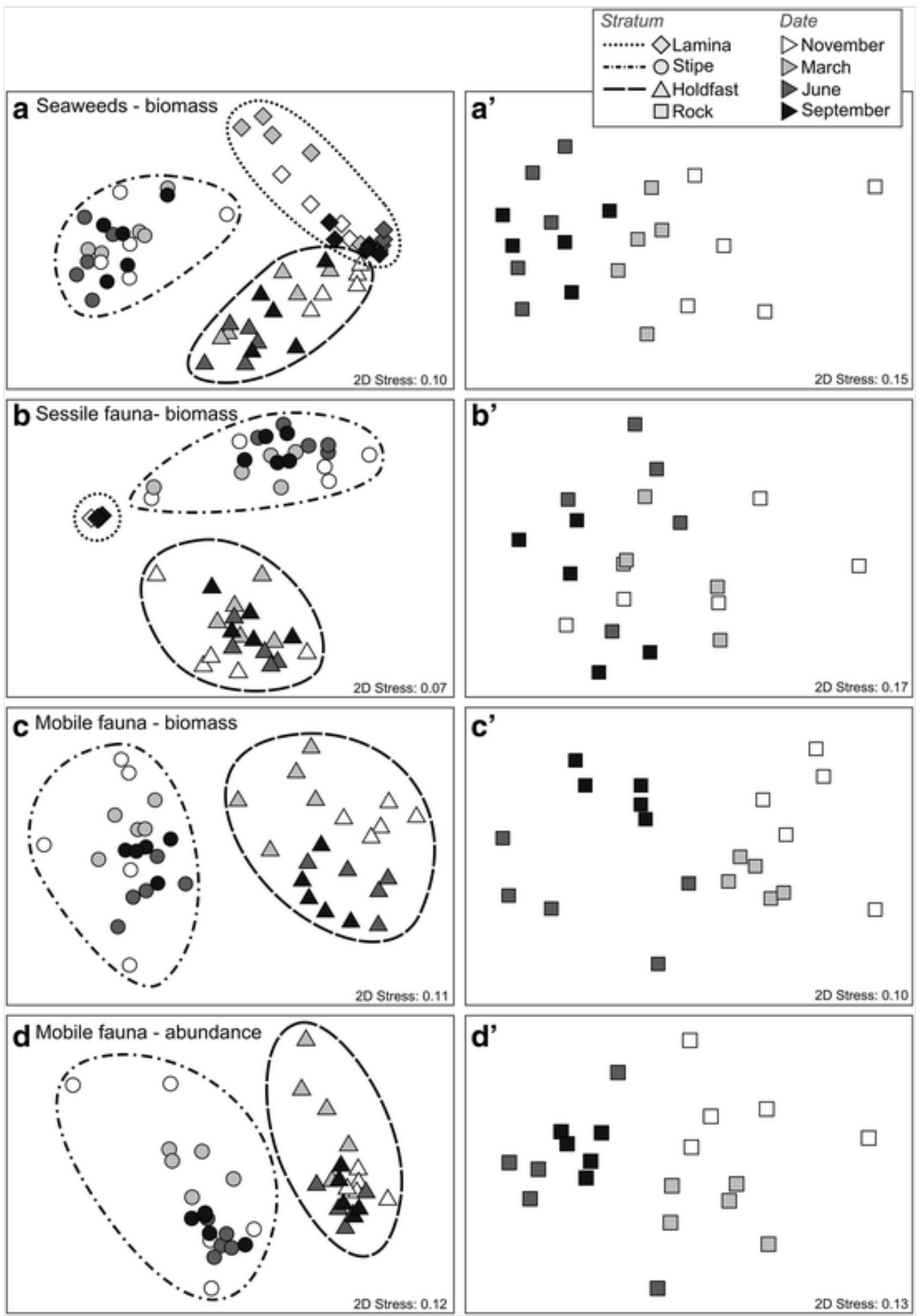

Rock substratum Sub-heading of "Seaweeds"... if possible please italicize it...

On the rock substratum, a total of 86 seaweeds were identified. According to the PERMANOVAs, seaweed species richness and biomass distribution varied greatly among sampling dates (Table 2). Seaweed richness (Fig. $3 \mathrm{~d}$ ) ranged from $S=15$ in November to $S=33-37$ in March-June and decreased between June and September $(S=30)$. Biomass distribution differed significantly 
between all consecutive sampling dates, except between June and September (Fig. $4 \mathrm{a}^{\prime}$; Table 2). Epilithic biomass was minimal in November for the dominant species (Appendix E-Suppplementary material 5), including seven species that grew during winter and accounted for the first $50 \%$ of the dissimilarity between November and March. The dissimilarity between March and June was mainly explained by the growth of several species, whose biomass peaked either in June (e.g. Dilsea carnosa, Polyneura bonnemaisonii, Sphaerococcus coronopifolius) or September (e.g. Phyllophora crispa, Calliblepharis ciliata and Heterosiphonia plumosa).

\section{Sessile fauna}

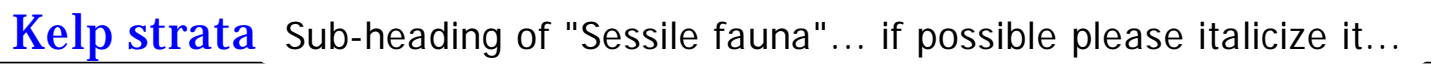

On kelp plants, the richness and biomass abundance distribution of sessile fauna differed significantly among sampling dates, but pairwise procedures failed to detect any consistent temporal pattern (Fig. 4b; Table 2). A total of 5 species occurred on laminae $(0.6 \pm 0.7$, Fig. $3 \mathrm{a}), 65$ on stipes $(25.1 \pm 5.0$, Fig. $3 \mathrm{~b})$ and 87 on and within holdfasts $(28.3 \pm 5.6$, Fig. $3 \mathrm{c})$. On laminae, biomass was dominated by Membranipora membranacea and Diplosoma listerianum (Appendix F-Suppplementary material 6). On stipes, biomass was dominated by bryozoans and ascidians growing on epiphytes (e.g. Electra pilosa, Alcyonidium gelatinosum, Trididemnum sp., and Botryllus schlosseri) and sponges and bryozoans growing on the stipe itself (e.g. Ophlitaspongia papilla, Halisarca dujardinii, Phaeostachys spinifera, Crisia denticulata and Celleporina calciformis) (Appendix F-Suppplementary material 6). On holdfasts and among haptera, sessile fauna biomass was dominated by sponges (e.g. Myxilla sp., Haliclona sp. and Amphilectus fucorum) and ascidians (Didemnum maculosum) (Appendix F-Suppplementary material 6).

Rock substratum Sub-heading of "Sessile fauna"... if possible please italicize it...

On the rock substratum, although sessile fauna richness (72 species on total) did not differ among sampling dates (28.8 \pm 5.9 , Fig. $3 \mathrm{~d})$, biomass distribution varied significantly, particularly between March and June (Fig. $4 b^{\prime}$; Table 2). According to the SIMPER analysis (Appendix F-Suppplementary material 6 ), this change was mainly explained by a decrease in the biomass of dominant epilithic sponges (i.e. Dysidea fragilis, Amphilectus fucorum), and in the growth of bryozoans and ascidians associated with seaweeds (e.g. Electra pilosa, Aplidium pallidum). 
Kelp strata Sub-heading of "Mobile fauna"... if possible please italicize it...

On kelp plants, mobile fauna richness differed among strata and among sampling dates, June and September being more diversified (Table 3 ). A total of 123 species were found on stipes and adjoining laminae ( $31.5 \pm 10.5$, Fig. $3 \mathrm{~b})$ and 158 within holdfasts $(47.5 \pm 12.7$, Fig. $3 \mathrm{c})$. Regardless of whether biomass or numerical abundance was considered, mobile fauna distribution varied significantly among sampling periods (Fig. 4c, d; Table 3 ) and pairwise tests indicated important temporal changes on both holdfasts and stipes with adjoining lamina. In all cases, the multivariate dispersion was not uniform among sampling periods (PERMDISP) and PERMANOVA results may indicate a combination of changes in abundance distribution among dates (multivariate location) and among kelp plants (multivariate dispersion).

\section{Table 3}

Results of PERMANOVA tests for differences in species richness and abundance (bio fauna on kelp and rock

\begin{tabular}{|c|c|c|c|c|c|c|c|}
\hline & & \multicolumn{6}{|c|}{ Mobile fauna } \\
\hline & & \multicolumn{3}{|c|}{ Richness S } & \multicolumn{3}{|c|}{$\begin{array}{l}\text { Biomass abundance } \\
\text { distribution }\end{array}$} \\
\hline \multicolumn{2}{|l|}{ Trans formation } & \multicolumn{3}{|l|}{ None } & \multicolumn{3}{|c|}{ Square root + dummy } \\
\hline \multicolumn{2}{|c|}{ Distance/similarity } & \multicolumn{3}{|c|}{ Euclidean distance } & \multicolumn{3}{|c|}{ Bray-Curtis similarity } \\
\hline & df & MS & Pseudo- $F$ & $\boldsymbol{P}$ & MS & Pseudo- $F$ & $\boldsymbol{P}$ \\
\hline \multicolumn{8}{|l|}{ Source: kelp } \\
\hline Age & 1 & 1435.0 & 18.9 & $<0.001$ & 1302.0 & 3.6 & 0.00 \\
\hline Stratum & 1 & 2560.0 & 15.9 & 0.037 & 14100.0 & 42.6 & $<\mathbf{0 . 0}$ \\
\hline Date & 3 & 455.3 & 9.7 & $<0.001$ & 1510.7 & 1.5 & 0.04 \\
\hline Kelp (date) & 15 & 46.8 & 0.6 & 0.800 & 362.6 & 1.1 & $0.25 c$ \\
\hline Stratum $\times$ date & 3 & 161.3 & 2.2 & 0.133 & 869.3 & 2.6 & $<\mathbf{0 . 0}$ \\
\hline Res. & 16 & 73.4 & & & 331.1 & & \\
\hline PERMDISP & & \multicolumn{2}{|c|}{$\begin{array}{l}F_{1,38}=1.616 \\
P \stackrel{=0.229}{ }\end{array}$} & & \multicolumn{2}{|c|}{$F_{3,36}=7.452, P=\mathbf{0 . 0 0 1}$} & \\
\hline
\end{tabular}

PERMDISP tests for differences in multivariate dispersion around the centroid amon

Significant $P$ values $(<0.05)$ are in bold. Pairwise tests are summarised $(N$ November, 
Mobile fauna

Richness S

Biomass abundance

dis tribution

\begin{tabular}{|r|l|l|l|l|l|l|}
\hline Transformation & \multicolumn{2}{l|}{ None } & \multicolumn{2}{l}{ Square root + dummy } \\
\hline Distance/similarity & \multicolumn{2}{|l|}{ Euclidean distance } & Bray-Curtis similarity \\
\hline df & MS & Pseudo- $\boldsymbol{F}$ & $\boldsymbol{P}$ & MS & Pseudo- $\boldsymbol{P}$ & $\boldsymbol{P}$ \\
\hline & & & & $\mathrm{N}>\mathrm{M}=\mathrm{J}=\mathrm{S}(<\mathrm{l}$ \\
\hline
\end{tabular}

Source: rock

\begin{tabular}{|c|c|c|c|c|c|c|c|}
\hline Date & 3 & 570.3 & 7.8 & $<0.001$ & 1788.7 & 4.3 & $<\mathbf{0 . 0}$ \\
\hline Res. & 16 & 72.9 & & & 412.6 & & \\
\hline PERMDISP & & \multicolumn{2}{|c|}{$\begin{array}{l}F_{3,16}=2.272 \\
P=0.181\end{array}$} & & \multicolumn{3}{|c|}{$F_{3,16}=13.156, P=\mathbf{0 . 0 0 4}$} \\
\hline & & & & & & \multicolumn{2}{|c|}{$\mathrm{N}>\mathrm{M}<\mathrm{J}=\mathrm{S}(<$} \\
\hline
\end{tabular}

Pairwise tests

\begin{tabular}{l|l|l|l}
$\begin{array}{l}\text { Kelp } \\
\text { parts: }\end{array}$ & $\begin{array}{l}\mathbf{N}=\mathbf{M}<\mathbf{J}=\mathbf{S} \\
(=\mathbf{N})\end{array}$ & Stipe/Lam.: & $\begin{array}{l}\mathbf{N} \neq \mathbf{M} \neq \mathbf{J} \neq \mathbf{S} \\
(\neq \mathbf{N})\end{array}$ \\
\hline Rock: & $\begin{array}{l}\mathbf{N}=\mathbf{M}<\mathbf{J}=\mathbf{S} \\
(>\mathbf{N})\end{array}$ & Holdfast: & $\begin{array}{l}\mathbf{N} \neq \mathbf{M} \neq \mathbf{J} \neq \mathbf{S} \\
(\neq \mathbf{N})\end{array}$ \\
\hline
\end{tabular}

PERMDISP tests for differences in multivariate dispersion around the centroid amon Significant $P$ values $(<0.05)$ are in bold. Pairwise tests are summarised $(N$ November,

Despite a relative temporal stability in habitat features on stipe and lamina, the multivariate dispersion of biomass distribution was higher in November compared with the other periods (PERMDISP pairwise tests, Table 3 ), especially on stipes (Fig. $4 \mathrm{c}, \mathrm{d}$ ). Careful examination of nMDS plots (Fig. $4 \mathrm{c}, \mathrm{d}$ ) confirmed the combination of the temporal patterns revealed by both PERMDISP and PERMANOVA, with precaution required regarding the differences between November and the other periods for stipes. The dissimilarity was mainly explained by differential change in abundance of the dominant species (Table 4). Grazer biomass peaked either in November for species living on laminae (e.g. Patella pellucida) or in June for species mainly associated with stipe epiphytes (e.g. Platynereis dumerilii, Lacuna parva, Tricolia pullus). Except for Calliostoma zizyphinum whose biomass peaked 
in November on the stipe, predator biomass decreased from November to March and peaked in June for the most numerically abundant species (e.g. Asterina gibbosa and Hippolyte varians, see also Appendix $\mathrm{G}$-Suppplementary material 7).

\section{Table 4}

Results of SIMPER analyses of Bray-Curtis similarity among consecutive sampling c associated with the different kelp forest strata

\begin{tabular}{l|l|l|l|l|l|l|}
\multirow{2}{*}{ Phy } & \multirow{3}{*}{ TG } & \multicolumn{2}{|l|}{ November } & \multicolumn{2}{l|}{ March } & June \\
\cline { 3 - 5 } & Ab. & $-{ }_{j} \%_{\text {Mar-Jun }}$ & Ab. & ${ }^{j} \%_{\text {Mar-Jun }}$ & Ab. \\
\hline
\end{tabular}

Stipe/lamina

\begin{tabular}{|c|c|c|c|c|c|c|c|c|}
\hline $\begin{array}{l}\text { Platynereis } \\
\text { dumerilii }\end{array}$ & Ann & $\mathrm{G}$ & 2.8 & 2.1 & 2.1 & 3.8 & 6.1 & 1 \\
\hline $\begin{array}{c}\text { Gibbula } \\
\text { cineraria }\end{array}$ & Mol & $\mathrm{G}$ & 4.3 & 8.3 & 8.5 & 7.4 & 10.3 & 6 \\
\hline $\begin{array}{l}\text { Patella } \\
\text { pellucida }\end{array}$ & Mol & $\mathrm{G}$ & 10.4 & 7.8 & 2.7 & 1.1 & 3.3 & 3 \\
\hline Lacuna parva & Mol & G & 0.7 & 0.6 & 0.0 & 2.0 & 2.1 & 1 \\
\hline Tricolia pullus & Mol & $\mathrm{G}$ & 0.6 & 0.5 & 0.6 & 1.3 & 1.7 & 1 \\
\hline Pista elongata & Ann & $\mathrm{SF}$ & 0.2 & 0.8 & 0.7 & 1.6 & 2.2 & 0 . \\
\hline $\begin{array}{l}\text { Asterina } \\
\text { gibbosa }\end{array}$ & Ech & sf-P & 4.5 & 5.8 & 3.4 & 2.2 & 4.9 & 1 \\
\hline $\begin{array}{l}\text { Calliostoma } \\
\text { zizyphinum }\end{array}$ & Mol & sf-P & 8.0 & 8.1 & 0.0 & 0.0 & 0.0 & 0 . \\
\hline $\begin{array}{l}\text { Acanthochitona } \\
\text { crinita }\end{array}$ & Mol & sf-P & 0.0 & 1.1 & 1.0 & 1.6 & 1.9 & 1 \\
\hline Trivia arctica & Mol & sf-P & 0.0 & 0.0 & 0.0 & 2.3 & 2.3 & 2 . \\
\hline $\begin{array}{l}\text { Hippolyte } \\
\text { varians }\end{array}$ & Art & $\mathrm{mf}-\mathrm{P}$ & 0.6 & 0.4 & 0.0 & 1.3 & 1.4 & $\mathbf{1}$ \\
\hline \multicolumn{9}{|l|}{ Holdfast } \\
\hline $\begin{array}{l}\text { Platynereis } \\
\text { dumerilii }\end{array}$ & Ann & G & 6.0 & 1.9 & 3.2 & 3.8 & 9.2 & $\mathbf{1}$ \\
\hline
\end{tabular}

Fauna average abundances (Ab.) were square-root-transformed. Relative contribution $(j \%)$ between consecutive sampling dates are presented depending on PERMANOV Species abundances and contribution to dissimilarity for species found in the cut-off 1 comparisons. Phy Phylum (Ann Annelida, Mol Mollusca, Art Arthropoda, Ech Echinc (Trophic group): $G$ Grazer, $D F$ Deposit-feeder, $S F$ Suspension-feeder, $s f-P$ sessile faur Predator. Species authorities are given in Appendix D-Suppplementary material 4 


\begin{tabular}{|c|c|c|c|c|c|c|c|c|}
\hline & \multirow[b]{2}{*}{ Phy } & \multirow[b]{2}{*}{$\mathbf{T G}$} & \multicolumn{2}{|c|}{ November } & \multicolumn{2}{|c|}{ March } & \multicolumn{2}{|c|}{ June } \\
\hline & & & Ab. & $\bar{j} \% \%_{\text {Mar-Jun }}$ & Ab. & $\bar{j}^{j} \%_{\text {Mar-Jun }}$ & Ab. & - \\
\hline $\begin{array}{l}\text { Eupolymnia } \\
\text { nesidensis }\end{array}$ & Ann & DF & 7.2 & 1.8 & 4.8 & 1.2 & 5.7 & 0. \\
\hline $\begin{array}{l}\text { Nicolea } \\
\text { venustula }\end{array}$ & Ann & DF & 5.4 & 1.3 & 4.6 & 1.9 & 5.3 & 1. \\
\hline $\begin{array}{l}\text { Polycirrus } \\
\text { medusa }\end{array}$ & Ann & DF & 4.2 & 2.7 & 5.3 & 3.1 & 0.7 & 0. \\
\hline $\begin{array}{l}\text { Thelepus } \\
\text { setosus }\end{array}$ & Ann & $\mathrm{DF}$ & 0.1 & 0.1 & 0.0 & 1.2 & 2.0 & $\mathbf{1}$ \\
\hline $\begin{array}{l}\text { Maera } \\
\text { inaequipes }\end{array}$ & Art & $\mathrm{DF}$ & 1.1 & 0.5 & 0.3 & 1.0 & 1.9 & 0 . \\
\hline $\begin{array}{l}\text { Branchiomma } \\
\text { bombyx }\end{array}$ & Ann & $\mathrm{SF}$ & 4.3 & 1.4 & 5.6 & 1.1 & 5.1 & $\mathbf{0}$ \\
\hline $\begin{array}{l}\text { Pisidia } \\
\text { longicornis }\end{array}$ & Art & $\mathrm{SF}$ & 5.0 & 1.1 & 3.3 & 2.1 & 6.4 & 1 . \\
\hline Ocnus lacteus & Ech & $\mathrm{SF}$ & 1.1 & 0.6 & 0.6 & 1.5 & 2.8 & 1. \\
\hline $\begin{array}{l}\text { Acanthochitona } \\
\text { crinita }\end{array}$ & Mol & sf-P & 0.4 & 0.8 & 1.5 & 1.0 & 1.2 & $\mathbf{0}$ \\
\hline $\begin{array}{l}\text { Ocinebrina } \\
\text { aciculata }\end{array}$ & Mol & sf-P & 1.3 & 0.7 & 0.5 & 0.7 & 1.3 & 1. \\
\hline $\begin{array}{l}\text { Asterina } \\
\text { gibbosa }\end{array}$ & Ech & sf-P & 1.0 & 1.5 & 2.8 & 1.6 & 0.6 & 1 . \\
\hline Eualus occultus & Art & $\mathrm{mf}-\mathrm{P}$ & 2.4 & 1.4 & 0.0 & 0.0 & 0.0 & $\mathbf{0}$ \\
\hline $\begin{array}{l}\text { Pilumnus } \\
\text { hirtellus }\end{array}$ & Art & $\mathrm{mf}-\mathrm{P}$ & 23.8 & 11.4 & 5.3 & 5.6 & 9.5 & 3 \\
\hline $\begin{array}{l}\text { Lepidonotus } \\
\text { clava }\end{array}$ & Ann & $\mathrm{mf}-\mathrm{P}$ & 2.1 & 1.3 & 0.0 & 1.5 & 2.3 & $\mathbf{1}$ \\
\hline $\begin{array}{l}\text { Harmothoe } \\
\text { extenuata }\end{array}$ & Ann & $\mathrm{mf}-\mathrm{P}$ & 2.1 & 1.1 & 0.8 & 1.3 & 2.2 & $\mathbf{1}$ \\
\hline $\begin{array}{l}\text { Lysidice } \\
\text { ninetta }\end{array}$ & Ann & $\mathrm{mf}-\mathrm{P}$ & 1.7 & 0.9 & 1.0 & 1.2 & 2.2 & 1 \\
\hline Mysta picta & Ann & $\mathrm{mf}-\mathrm{P}$ & 0.7 & 0.4 & 0.0 & 0.6 & 1.0 & 0 \\
\hline
\end{tabular}

Fauna average abundances (Ab.) were square-root-transformed. Relative contribution $(j \%)$ between consecutive sampling dates are presented depending on PERMANOV Species abundances and contribution to dissimilarity for species found in the cut-off $]$ comparisons. Phy Phylum (Ann Annelida, Mol Mollusca, Art Arthropoda, Ech Echinc (Trophic group): $G$ Grazer, $D F$ Deposit-feeder, $S F$ Suspension-feeder, $s f-P$ sessile faur Predator. Species authorities are given in Appendix D-Suppplementary material 4 


\begin{tabular}{|c|c|c|c|c|c|}
\hline \multirow{2}{*}{ Phy } & \multirow{2}{*}{ TG } & \multicolumn{2}{|c|}{ November } & \multicolumn{2}{|c|}{ March } \\
\hline & & Ab. & ${ }^{-} \%_{\text {Mar-Jun }}$ & Ab. & ${ }^{-j} \%_{\text {Mar-Jun }}$ \\
\hline
\end{tabular}

Ab.

Rock

\begin{tabular}{|c|c|c|c|c|c|c|c|c|}
\hline Lacuna parva & Mol & G & 3.3 & 2.3 & 0.1 & 1.1 & 2.1 & 0. \\
\hline $\begin{array}{l}\text { Barleeia } \\
\text { unifasciata }\end{array}$ & Mol & G & 1.9 & 1.2 & 3.3 & 1.8 & 5.0 & 1 \\
\hline $\begin{array}{l}\text { Gibbula } \\
\text { cineraria }\end{array}$ & Mol & G & 0.0 & 0.8 & 1.2 & 1.7 & 3.9 & 1. \\
\hline Rissoa parva & Mol & G & 4.4 & 1.4 & 2.5 & 0.6 & 2.2 & 1. \\
\hline Tricolia pullus & Mol & G & 1.6 & 0.7 & 2.0 & 0.9 & 3.3 & 0 . \\
\hline Cymodoce sp. & Art & G & 0.0 & 0.0 & 0.0 & 0.3 & 0.5 & 0. \\
\hline $\begin{array}{l}\text { Dexamine } \\
\text { spinosa }\end{array}$ & Art & G & 0.4 & 0.4 & 0.3 & 0.6 & 1.3 & $\mathbf{0}$ \\
\hline $\begin{array}{l}\text { Bittium } \\
\text { reticulatum }\end{array}$ & Mol & DF & 4.2 & 1.1 & 4.1 & 2 & 7.3 & $\mathbf{0}$ \\
\hline $\begin{array}{l}\text { Nucula sp. A. } \\
\text { hanleyi }\end{array}$ & Mol & DF & 0.0 & 0.0 & 0.0 & 0.9 & 1.9 & $\mathbf{0}$ \\
\hline $\begin{array}{l}\text { Amphicteis } \\
\text { gunneri }\end{array}$ & Ann & DF & 0.0 & 0.0 & 0.0 & 0.9 & 1.9 & 0. \\
\hline $\begin{array}{l}\text { Eupolymnia } \\
\text { nesidensis }\end{array}$ & Ann & DF & 1.5 & 1.3 & 3.4 & 1 & 2.0 & 0. \\
\hline $\begin{array}{l}\text { Nephasoma } \\
\text { minutum }\end{array}$ & Sip & DF & 0.4 & 0.3 & 0.4 & 0.8 & 1.8 & 0 . \\
\hline Abra sp. A. alba & Mol & SF & 0.0 & 0.0 & 0.0 & 1.1 & 2.2 & $\mathbf{0}$ \\
\hline Pista elongata & Ann & SF & 2.8 & 0.9 & 3.2 & 1.1 & 4.8 & 1. \\
\hline $\begin{array}{l}\text { Aora } \\
\text { spinicornis }\end{array}$ & Art & SF & 0.6 & 0.3 & 0.2 & 0.7 & 1.4 & 0. \\
\hline Antedon bifida & Ech & SF & 3.5 & 1.7 & 2.5 & 0.8 & 1.2 & 0. \\
\hline $\begin{array}{l}\text { Acanthochitona } \\
\text { crinita }\end{array}$ & Mol & sf-P & 0.0 & 0.4 & 0.6 & 0.6 & 1.2 & 0. \\
\hline $\begin{array}{l}\text { Nassarius } \\
\text { incrassatus }\end{array}$ & Mol & sf-P & 0.0 & 1.0 & 1.4 & 1 & 1.5 & 0. \\
\hline
\end{tabular}

Fauna average abundances $(\mathrm{Ab}$.) were square-root-transformed. Relative contribution $(j \%)$ between consecutive sampling dates are presented depending on PERMANOV Species abundances and contribution to dissimilarity for species found in the cut-off 1 comparisons. Phy Phylum (Ann Annelida, Mol Mollusca, Art Arthropoda, Ech Echinc (Trophic group): $G$ Grazer, $D F$ Deposit-feeder, $S F$ Suspension-feeder, $s f-P$ sessile faur Predator. Species authorities are given in Appendix D-Suppplementary material 4 


\begin{tabular}{|c|c|c|c|c|c|c|c|c|}
\hline & \multirow[b]{2}{*}{ Phy } & \multirow[b]{2}{*}{$\mathbf{T G}$} & \multicolumn{2}{|c|}{ November } & \multicolumn{2}{|c|}{ March } & \multicolumn{2}{|c|}{ June } \\
\hline & & & Ab. & $\overline{-}_{j} \%_{\text {Mar-Jun }}$ & Ab. & ${ }_{j} \%_{\text {Mar-Jun }}$ & Ab. & - \\
\hline Trivia arctica & Mol & sf-P & 2.2 & 1.8 & 1.3 & 0.8 & 0.0 & $\mathbf{0}$ \\
\hline $\begin{array}{l}\text { Asterina } \\
\text { gibbosa }\end{array}$ & Ech & sf-P & 9.4 & 2.2 & 6.6 & 1.8 & 3.5 & 1. \\
\hline $\begin{array}{l}\text { Lysianassa } \\
\text { ceratina }\end{array}$ & Art & $\mathrm{mf}-\mathrm{P}$ & 1.1 & 0.8 & 1.7 & 1.1 & 2.3 & $\mathbf{0}$ \\
\hline $\begin{array}{l}\text { Hippolyte } \\
\text { varians }\end{array}$ & Art & $\mathrm{mf}-\mathrm{P}$ & 0.0 & 0.0 & 0.0 & 1.1 & 2.0 & $\mathbf{0}$ \\
\hline $\begin{array}{l}\text { Anapagurus } \\
\text { hyndmanni }\end{array}$ & Art & $\mathrm{mf}-\mathrm{P}$ & 1.8 & 1.3 & 0.6 & 0.5 & 1.4 & 0. \\
\hline Eualus cranchii & Art & $\mathrm{mf}-\mathrm{P}$ & 0.5 & 0.3 & 0.0 & 0.0 & 0.0 & $\mathbf{0}$ \\
\hline $\begin{array}{l}\text { Eurynome } \\
\text { spinosa }\end{array}$ & Art & $\mathrm{mf}-\mathrm{P}$ & 0.4 & 0.4 & 0.2 & 0.6 & 1.2 & $\mathbf{0}$ \\
\hline Necora puber & Art & $\mathrm{mf}-\mathrm{P}$ & 0.0 & 0.0 & 0.0 & 0.9 & 1.7 & 0. \\
\hline $\begin{array}{l}\text { Pirimela } \\
\text { denticulata }\end{array}$ & Art & $\mathrm{mf}-\mathrm{P}$ & 0.3 & 0.2 & 0.0 & 0.7 & 1.3 & 0. \\
\hline $\begin{array}{l}\text { Achaeus } \\
\text { cranchii }\end{array}$ & Art & $\mathrm{mf}-\mathrm{P}$ & 0.4 & 0.3 & 0.0 & 3.2 & 6.0 & 2. \\
\hline $\begin{array}{l}\text { Achelia } \\
\text { echinata }\end{array}$ & Art & $\mathrm{mf}-\mathrm{P}$ & 0.5 & 0.3 & 0.2 & 0.1 & 0.0 & $\mathbf{0}$ \\
\hline Endeis spinosa & Art & $\mathrm{mf}-\mathrm{P}$ & 0.7 & 0.5 & 0.0 & 0.9 & 1.5 & 1. \\
\hline $\begin{array}{l}\text { Nymphon } \\
\text { gracile }\end{array}$ & Art & $\mathrm{mf}-\mathrm{P}$ & 0.0 & 0.4 & 0.7 & 1.1 & 2.5 & 0. \\
\hline
\end{tabular}

Fauna average abundances (Ab.) were square-root-transformed. Relative contribution $(-j \%)$ between consecutive sampling dates are presented depending on PERMANOV Species abundances and contribution to dissimilarity for species found in the cut-off ] comparisons. Phy Phylum (Ann Annelida, Mol Mollusca, Art Arthropoda, Ech Echinc (Trophic group): $G$ Grazer, $D F$ Deposit-feeder, $S F$ Suspension-feeder, $s f-P$ sessile faur Predator. Species authorities are given in Appendix D-Suppplementary material 4

As on the stipe, the biomass distribution of the mobile fauna inhabiting holdfast changed throughout the year (Table 3 ). Among the species that contributed predominantly to the dissimilarities between consecutive sampling dates, some abundance patterns were observed (Table 4; Appendix G-Suppplementary material 7). Within holdfasts, the biomass of the grazer annelid species Platynereis dumerilii decreased between November and March and then increased until September. The main particle-feeders showed 
contrasting patterns. Among them, the biomass of the annelids Polycirrus medusa and Branchiomma bombyx peaked in March, whereas Eupolymnia nesidensis and Nicolea venustula peaked in November. Although numerical abundance of most predators peaked in November within holdfasts (Appendix G-Suppplementary material 7), the temporal patterns in biomass were less consistent throughout the year (e.g. two peaks for Pilumnus hirtellus, Asterina gibbosa, Harmothoe extenuata), likely resulting from the large range of body size observed among holdfasts.

Rock substratum Sub-heading of "Mobile fauna"... if possible please italicize it...

On the rock substratum, a total of 201 mobile fauna species were found and the richness varied over the year (Table 3 ). Average mobile fauna richness was minimal in November-March $(42.4 \pm 6.9)$ and maximal in June-September $(60.1 \pm 9.9$, Fig. 2 d). Regardless of whether biomass or numerical abundance was considered, mobile fauna distribution (as well as multivariate dispersion, both checked on nMDS) differed significantly among all sampling periods (Table 3 ). Among the 31 species which accounted for the first $50 \%$ of pairwise dissimilarities between consecutive sampling dates, there were species-specific temporal patterns, even within phyla or trophic groups (Table 4).

Most grazers decreased in biomass and numerical abundance (Appendix G-Suppplementary material 7) between November and March, and reached maximum values either in June (Tricolia pullus, Gibbula cineraria) or in September (Lacuna parva, Barleeia unifasciata, Rissoa parva, Cymodoce sp. Dexamine spinosa). Unlike grazers, most deposit- and suspension-feeders increased in numerical and biomass abundance from November to March, but biomass peaked either in November (Antedon bifida), March (Eupolymnia nesidensis), June (Bittium reticulatum, Nephasoma minutum, Amphicteis gunneri, Nucula sp., Aora spinicornis) or September (Pista elongata). For most predators, maximum biomass was observed either in November (e.g. Trivia arctica, Asterina gibbosa), June (e.g. Necora puber, Pirimela denticulata, Achaeus cranchii) or September (e.g. Acanthochitona crinita, Nassarius incrassatus, Hippolyte varians, Endeis spinosa).

\section{Relationship between habitat complexity and mobile fauna distribution}

On kelp plants, variability in mobile fauna distribution appeared strongly 
linked with epiphytic habitat size (Table 5), and significant rank correlations were observed among the biomass distributions of morpho-functional groups and mobile fauna biomass and numerical distribution (Table 6). Although modest, significant relationships were also observed between biomass distribution of mobile fauna and morpho-functional groups on both stipe and holdfast, whereas stipe surface area or holdfast interstitial volume were not correlated with mobile fauna (Table 6).

\section{Table 5}

Results of PERMANOVA tests for differences in species richness and abundance (biot mobile fauna on the different kelp strata and rock, taking into account Habitat size as a co

\section{Mobile fauna}

\section{Richness S}

None

Transformation

Euclidean distance

Distance/similarity

\section{Biomass abundance distri.}

Square root + dummy

Bray-Curtis similarity

MS Pseudo- $F \quad P$

Source: stipe/lamina

\begin{tabular}{|l|l|l|l|l|l|l|l|}
\hline $\begin{array}{l}\text { Habitat } \\
\text { amountsize }\end{array}$ & 1 & 382.4 & 3.0 & 0.130 & 1356.5 & 4.0 & $\mathbf{0 . 0 1 7}$ \\
\hline Date & 3 & 48.0 & 0.4 & 0.785 & 791.4 & 2.3 & $\mathbf{0 . 0 0 2}$ \\
\hline $\begin{array}{l}\text { Habitat } \\
\text { amountsize } \times \text { date }\end{array}$ & 3 & 17.5 & 0.1 & 0.915 & 173.9 & 0.5 & 0.938 \\
\hline Res. & 12 & 125.7 & & 339.7 & \\
\hline PERMDISP & & $F_{3,16}=2.242, P=0.195$ & $F_{3,16}=11.367, P<\mathbf{0 . 0 0 1}$ \\
\hline
\end{tabular}

Source: holdfast

\begin{tabular}{|l|l|l|l|l|l|l|l|}
\hline $\begin{array}{l}\text { Habitat } \\
\text { amountsize }\end{array}$ & 1 & 446.8 & 11.2 & $\mathbf{0 . 0 0 7}$ & 1142.2 & 3.0 & $\mathbf{0 . 0 0 2}$ \\
\hline Date & 3 & 455.3 & 11.4 & $\mathbf{0 . 0 0 1}$ & 1334.4 & 3.6 & $<\mathbf{0 . 0 0 1}$ \\
\hline $\begin{array}{l}\text { Habitat } \\
\text { amountsize } \times \text { date }\end{array}$ & 3 & 260.5 & 6.5 & $\mathbf{0 . 0 0 5}$ & 398.8 & 1.1 & 0.378 \\
\hline
\end{tabular}

PERMDISP tests for differences in multivariate dispersion around the centroid amon presented. Significant $P$ values $(<0.05)$ are in bold. Pairwise tests are summarised $(N$ I $S$ September) 
Richness S

Biomass abundance distri.

\begin{tabular}{|c|c|c|c|c|c|c|c|}
\hline \multicolumn{2}{|l|}{ Transformation } & \multicolumn{3}{|c|}{ None } & \multicolumn{3}{|c|}{ Square root + dummy } \\
\hline \multicolumn{2}{|l|}{ Distance/similarity } & \multicolumn{3}{|c|}{ Euclidean distance } & \multicolumn{3}{|c|}{ Bray-Curtis similarity } \\
\hline & df & MS & Pseudo-F & $\boldsymbol{P}$ & MS & Pseudo-F & $\boldsymbol{P}$ \\
\hline Res. & 12 & 40.1 & & & 375.7 & & \\
\hline PERMDISP & & \multicolumn{3}{|c|}{$F_{3,16}=1.705, P=0.328$} & \multicolumn{3}{|c|}{$F_{3,16}=4.235, P=\mathbf{0 . 0 4 7}$} \\
\hline \multicolumn{8}{|l|}{ Source: rock } \\
\hline $\begin{array}{l}\text { Habitat } \\
\text { amountsize }\end{array}$ & 1 & 497.7 & 7.0 & 0.024 & 1704.2 & 4.6 & $<0.001$ \\
\hline Date & 3 & 438.6 & 6.2 & 0.010 & 1388.4 & 3.8 & $<0.001$ \\
\hline $\begin{array}{l}\text { Habitat } \\
\text { amountsize } \times \text { date }\end{array}$ & 3 & 71.7 & 1.0 & 0.426 & 556.3 & 1.5 & 0.027 \\
\hline Res. & 12 & 70.8 & & & 369.1 & & \\
\hline PERMDISP & & \multicolumn{3}{|c|}{$F_{3,16}=2.272, P=0.181$} & \multicolumn{3}{|c|}{$F_{3,16}=13.156, P=\mathbf{0 . 0 0 4}$} \\
\hline & & & & & \multicolumn{2}{|c|}{$\begin{array}{l}\mathrm{N}>\mathrm{M}<\mathrm{J}=\mathrm{S} \\
(<\mathrm{N})\end{array}$} & \\
\hline \multicolumn{8}{|l|}{ Pairwise tests } \\
\hline Stipe/lamina & & & & & \multicolumn{2}{|c|}{$\begin{array}{l}\mathbf{N}=\mathbf{M} \neq \mathbf{J} \neq \mathbf{S} \\
(=\mathbf{N})\end{array}$} & \\
\hline Holdfast & & \multicolumn{2}{|c|}{$\begin{array}{l}\mathbf{N}>\mathbf{M}<\mathbf{J}=\mathbf{S} \\
(=\mathbf{N})\end{array}$} & & \multicolumn{2}{|c|}{$\begin{array}{l}\mathbf{N} \neq \mathbf{M} \neq \mathbf{J} \neq \mathbf{S} \\
(\neq \mathbf{N})\end{array}$} & \\
\hline Rock & & \multicolumn{2}{|c|}{$\begin{array}{l}\mathbf{N}=\mathbf{M}<\mathbf{J}=\mathbf{S} \\
(>\mathbf{N})\end{array}$} & & \multicolumn{2}{|c|}{$\begin{array}{l}\mathbf{N} \neq \mathbf{M} \neq \mathbf{J} \neq \mathbf{S} \\
(\neq \mathbf{N})\end{array}$} & \\
\hline
\end{tabular}

PERMDISP tests for differences in multivariate dispersion around the centroid amon presented. Significant $P$ values $(<0.05)$ are in bold. Pairwise tests are summarised $(N$ I $S$ September)

\section{Table 6}

Results of RELATE procedure testing for correlations (Spearman rank-based $\rho$ ) among biological matrices (mobile fauna richness, biomass and numerical abundance distributions) and environmental matrices [habitat size and biomass distribution (BD) among morpho-functional groups] 


\section{\begin{tabular}{l|l|l} 
Richness S & $\begin{array}{l}\text { Biomass } \\
\text { distribution }\end{array}$ & $\begin{array}{l}\text { Numerical } \\
\text { distribution }\end{array}$
\end{tabular}}

\begin{tabular}{l|l|l} 
Euc. & B-C & B-C
\end{tabular}

Kelp (stipe + holdfast)

\begin{tabular}{|l|l|l|l|l|}
$\begin{array}{l}\text { Habitat size } \\
\text { (gAFDM) }\end{array}$ & Euc. & -0.02 & $\mathbf{0 . 3 1} * * *$ & $\mathbf{0 . 2 8} * * *$ \\
\hline $\begin{array}{l}\text { Morpho Groups } \\
\text { BD }\end{array}$ & B-C & $\mathbf{0 . 1 9} * *$ & $\mathbf{0 . 6 4} * * *$ & $\mathbf{0 . 5 8} * * *$ \\
\hline
\end{tabular}

Stipe

\begin{tabular}{l|l|l|l|l}
\hline $\begin{array}{c}\text { Stipe surface } \\
\text { area }\left(\mathrm{cm}^{2}\right)\end{array}$ & Euc. & 0.03 & -0.11 & -0.14 \\
\hline $\begin{array}{l}\text { Habitat size } \\
(\mathrm{gAFDM})\end{array}$ & Euc. & 0.21 & $\mathbf{0 . 2 3} *$ & 0.08 \\
\hline $\begin{array}{l}\text { Morpho Groups } \\
\text { BD }\end{array}$ & B-C & 0.13 & $\mathbf{0 . 3 0} *$ & $\mathbf{0 . 2 7 *}$ \\
\hline
\end{tabular}

Holdfast

\begin{tabular}{l|l|l|l|l}
\hline $\begin{array}{l}\text { Interstitial } \\
\text { volume (ml) }\end{array}$ & Euc. & 0.13 & 0.05 & 0.06 \\
\hline $\begin{array}{l}\text { Habitat size } \\
\text { (gAFDM) }\end{array}$ & Euc. & 0.06 & 0.13 & 0.07 \\
\hline $\begin{array}{c}\text { Morpho Groups } \\
\text { BD }\end{array}$ & B-C & 0.05 & $\mathbf{0 . 2 0 *}$ & 0.09 \\
\hline
\end{tabular}

Rock

\begin{tabular}{|l|l|l|l|l|}
$\begin{array}{l}\text { Habitat size } \\
\text { (gAFDM) }\end{array}$ & Euc. & 0.086 & $\mathbf{0 . 2 3} *$ & $\mathbf{0 . 1 8 *}$ \\
\hline $\begin{array}{c}\text { Morpho Groups } \\
\text { BD }\end{array}$ & B-C & $\mathbf{0 . 1 9 *}$ & $\mathbf{0 . 4 2} * * *$ & $\mathbf{0 . 5 3} * * *$ \\
\hline
\end{tabular}

Matrix type ( $D$ distance- or dissimilarity-based) is indicated (Euc. Euclidean distance, $B-C$ Bray-Curtis dissimilarity). Significant $\rho$ are in bold ( $* P<0.05$; $* * P<0.01 ; * * * P<0.001)$

As on kelp plants, variability in the distribution of mobile fauna appeared strongly linked with quantity of seaweed and sessile fauna (Table 5) and significant rank correlations were observed between biomass distribution of morpho-functional groups and mobile fauna biomass and numerical distribution (Table 6). However, depending on sampling date, habitat size did not explain the variability in biomass distribution of mobile fauna to the same 
extent (Table 5, significant interaction term), suggesting that additional processes were involved.

\section{Discussion}

Over the year of the survey, the kelp forest strata underwent different changes in habitat complexity. Habitat size and distribution among biogenic structural elements were relatively stable on kelp stipes and highly variable near the bottom (rock substratum). Despite contrasting variation in habitat complexity in all kelp forest strata, there were overall changes in richness and relative abundance distribution of mobile species.

\section{Dynamics and importance of habitat complexity}

Important changes in habitat complexity were observed in the sub-canopy layers (holdfast and rock) with minimal seaweed biomass in November, when most species appeared to decay, likely resulting from autumn senescence prior to winter reproduction (Kain, 1982; Whittick, 1983). From November to June, seaweed species richness and biomass (mainly made of rough-leaf-like and bushy species) increased in concert, whereas between June and September, the epilithic biomass remained similar for all biogenic morphofunctional groups, despite a reduction in seaweed richness and the loss of biomass in several species (Appendix E-Suppplementary material 5). The June-September period was also characterised by the highest mobile fauna species richness, which varied significantly with the sampling date and habitat size in the forest understorey stratum. This period was also characterised by maximal numerical abundances of many grazers (mainly gastropods) and particle-feeders (mainly amphipods), which may have benefited from the increase in surface area due to more complex seaweeds (Christie et al., 2007). With regard to multivariate analyses on biomass distribution of mobile fauna, however, the observed interaction between habitat size and date suggests that additive processes influence those temporal patterns. The relationship between mobile fauna distribution (biomass and numerical) and habitat complexity was twice as strong when considering the biomass distribution among morpho-functional groups $(\rho=0.42-0.53)$ rather than habitat size itself ( $\rho=0.23-0.18$, Table 6$)$, indicating that the non-linear relationship between biomass and complexity can differ among functional groups (Gee \& Warwick, 1994). Although significant, this habitat-fauna relationship was relatively modest $(\rho<0.6)$ and additional overlooked aspects of habitat complexity such as the spatial arrangement of the morpho-functional groups 
(Tokeshi \& Arakaki, 2012), whose abundances where not weighted according to their complexity in this study, may have altered these results.

Increasing habitat size and modifying distribution in morpho-functional groups can indirectly promote habitat complexity and heterogeneity by retaining sediment and associated species (Gibbons, 1988; McQuaid \& Dower, 1990). Among the numerous species contributing to the differences in macrofauna distribution between sampling dates, the psammophilic bivalves Abra sp. and Nucula sp. and the ampharetid annelid Amphicteis gunneri were patchily distributed in June, indicating supply and local burial of fine sediments. Sediment supply is of critical importance in rocky shore communities (Airoldi, 2003; Connell, 2005). For instance, burial can smother some epilithic sponge species and affect their survival (Littler et al., 1983 ; Maldonado et al., 2008 ). Overall, no macroalgal and fauna species were missing, indicating apparently moderate burial for most established species. While increasing understorey biomass (dominated by rough leaf-like and bushy seaweeds) may have facilitated sediment burial (Connell et al., 2014 ), it also promoted the availability of microhabitats above the sediment layer.

Complex microhabitats are often preferentially chosen by settlers and young development stages (Lee et al., 2004) as they provide good refuge against predators and physical disturbance (Jones, 1971; Dean \& Connell, 1987b; Lee et al., 2004). In L. hyperborea forests, large kelp holdfasts have been shown to shelter numbers of recruits and juveniles (Christie et al., 2003). In the present study, juveniles of the velvet crab Necora puber were found to be abundant among macroalgae of the sub-canopy in June-September, whereas crypto-benthic adults, abundant under boulders at the study site year-round (Leclerc et al., 2015, and unpub. data) were not sampled elsewhere during the rest of the survey. Within the kelp forest, highly complex understorey seaweeds thus have exacerbated patterns of temporal variation of species richness and community structure through nursery provision.

\section{Unique but linked: Microhabitats of the kelp forest}

Although contrasting patterns were observed among kelp strata (lamina, stipe and holdfast), the quantity and composition of morpho-functional groups were relatively stable on stipes that carried most of the epiphytic biomass.

Nonetheless, important temporal changes in mobile fauna richness and distribution were revealed across all kelp strata. 
On the annual laminae, the algal richness was reduced and varied little among sampling dates. Active growth of algal epiphytes occurred on the senescing laminae during the winter before they are sloughed off (Norton et al., 1977; Schultze et al., 1990). Temporal changes in the abundance of the blue-rayed limpet Patella pellucida (Table 4 ) were consistent with lamina turn-over, rather than that of epiphytes. This temporal pattern likely results from the synchrony between the limpet life cycle and that of the annual laminae on which it directly feeds (Toth \& Pavia, 2002), with recruitment occurring in spring on newly formed laminae and growth continuing until winter (Graham \& Fretter, 1947). Unlike laminae, stipes and holdfasts are perennial structures and intra-annual changes in associated complexity could be expected to vary with the life cycles of epiphytic species (Whittick, 1983; Christie et al., 2003 ). In the study site, the epiphytic habitat features remained relatively stable throughout the year. The biomass distribution of sessile fauna, including species growing on either epiphytes (mainly thin sheets) or on the stipe itself (mainly cushions and massive forms), did not change significantly among sampling dates. These results can be explained by the dominance of perennial red algae such as Palmaria palmata and Rhodymenia pseudopalmata and by the persistence as vegetative stages of senescent Delesseriaceae species during the winter (Norton et al., 1977; Whittick, 1983 ; Schultze et al., 1990). It is noteworthy that as P. palmata and $R$. pseudopalmata are both structurally simple seaweeds (smooth leaf-like) which - albeit preferred for their food value by several direct grazers - are generally associated with lower diversity of associated assemblages (Norderhaug, 2004; Christie et al., 2007). The relative contribution of those algae on stipes as compared to the understory may partly explain differences in richness between those strata, disregarding the possible confounding effect of their vertical positions (Jørgensen \& Christie, 2003; Christie et al., 2007).

Although the habitat size significantly accounted for the variability in mobile fauna richness and distribution (Table 5), it did not fully explain their temporal patterns. Most species exhibit strong preferences for specific microhabitats within kelp forests (Christie et al., 2003) and habitat affinity may vary with food availability (Leclerc et al., 2013). The predominance of several highly mobile taxa also implies a substantial connectivity among microhabitats, either horizontally among kelp plants or vertically among strata (Norderhaug et al., 2002; Waage-Nielsen et al., 2003). Thus, temporal patterns observed on the highly dynamic understorey may have influenced the changes in mobile species distribution within all the kelp strata. Nonetheless, 
the temporal variability observed on stipes was mainly explained by changes in the biomass of several gastropod grazers, whose dispersion abilities are relatively reduced as compared to other taxa. To date, how L. hyperborea canopies interact with the understorey remains unexplored (Smale et al., 2013 ) and further experimental approaches and larger scale investigations are required to fully interpret our results (e.g. Reed \& Foster, 1984; Kendrick et al., 1999; Connell, 2003 ; Wernberg \& Goldberg, 2008; Bennett et al., $2015)$.

\section{Possible role of trophic interactions}

Overall, mobile fauna experienced great changes in their relative abundances between November and March with contrasting trends among species. In cold and temperate waters, both temperature and food availability may explain winter mortality (and dormancy) of poikilotherm species dominating benthic communities (Coma et al., 2000). In the shallow well-mixed waters of Roscoff, temperature usually ranges solely from $8^{\circ} \mathrm{C}$ in February to $16^{\circ} \mathrm{C}$ in August, and diatom blooms $\left(1.0-3.0 \mu \mathrm{g} \mathrm{chl} a 1^{-1}\right)$ usually take place from mid-April to November (Wafar et al., 1983; Sournia \& Birrien, 1995 ). However, at the study site, large amounts of organic matter are supplied by kelp and red algae during autumn and by kelp throughout the winter, and can compensate for phytoplankton reduction during these relatively low production periods $\left(\approx 0.6 \mu \mathrm{g} \mathrm{chl} a l^{-1}\right.$ ) (Leclerc et al., 2013). In the present study, the biomass of several deposit- and suspension-feeders found within holdfasts (e.g. Polycirrus medusa, Branchiomma bombyx) and on the rock substratum (e.g. Eupolymnia nesidensis and Pista elongata) peaked in March, suggesting winter growth. Moreover, the biomass composition and species richness of sessile taxa (suspension-feeders) did not change during the winter period. These results suggest that particle-feeders subsisted over winter on food supply provided by surrounding macroalgae and decaying animals.

Unlike particle-feeders, grazing species need fresh macroalgae and may be differentially affected according to their food preferences and trophic plasticity (Miller-Rushing et al., 2010). The autumn senescence of several red algae species reduced their availability both as habitat and food and may affect specialised grazers, such as the snail Lacuna parva (Ockelmann \& Nielsen, 1981; Leclerc et al., 2013 ) whose biomass dramatically decreased between November and March (on both stipe and rock), without considering egg capsules found on Phycodrys rubens in March. In contrast, Platynereis dumerilii is less selective and feeds either on growing or drift macroalgae 
(Rasmussen, 1973; Bedford \& Moore, 1985), which may partly explain why P. dumerilii lost biomass to a smaller extent than L. parva between November and March. Stable isotope analyses conducted on P. dumerilii have suggested that their red alga grazing activity increased during winter growth (Leclerc et al., 2013 ). Given that $P$. dumerilii gained biomass as red algae grew and that no loss of macroalgal biomass was observed from March to September, grazing may prevail until autumnal senescence of red algae.

While plasticity in food utilisation may explain differences in variation of these two grazers, the interaction between habitat complexity and predation may also be invoked as an additional process. Lacuna gastropods have been found abundant in guts of Labriid fish associated with L. hyperborea forests (Norderhaug et al., 2005). Given the preference of Lacuna for smooth surfaces of seaweeds, it has been suggested that these grazers were more exposed to predators (Christie et al., 2007), as compared to species preferring hidden rough surfaces to build their tube (e.g. P. dumerilii). Overall, large fish and decapods (not sampled in this study) may benefit from lower habitat size and abundances of complex seaweeds in fall and exert substantial control on several mobile species. While such mediation of biological interactions by habitat complexity remains to be experimentally tested, it could explain species-specific changes in abundances observed in this study.

\section{Concluding remarks}

Collectively, our results clearly demonstrate that temporal changes in habitat complexity (as defined in our study) influence mobile fauna distribution across all kelp forest strata - though additional processes (such as predation, food availability) very likely interplay. Species biomass distributions may vary according to reproductive synchrony at the community level and successions in utilisation of both habitat and trophic resources. Matching between the life cycle of the specialised kelp grazer Patella pellucida and the annual lamina turn-over constitutes a well-known example. The dominant red algae are expected to reproduce and grow during winter, when the algal cover and grazer density are reduced on stipes and the rock substratum (Kain, 1976b, 1982). Rapidly however, these red algae are colonised by sessile and mobile fauna, and preferentially consumed by several grazers. Although grazers may contribute to the biomass loss of red algae at the end of their growth, natural senescence generally follows summer period. Senescence supplies large amount of particulate organic matter derived from macroalgae, which can compensate for the reduction in temperature and in phytoplankton production 
at this period. Organic matter sources vary seasonally or stochastically (e.g. sediment inputs), but their diversity leads to continuous supplies that can sustain high secondary production and promote local biodiversity. At local scale, habitat complexity influences species distribution, but temporal patterns likely involve a series of additional factors such as sediment cover and food availability. Given that both food supply and habitat complexity may covary with environmental conditions (Hay, 1981; Duggins et al., 2003; Schaal et al., 2009; Bekkby et al., 2014), canopy-understorey interactions in Laminaria hyperborea systems (Smale et al., 2013) and the respective contributions of the above-mentioned factors in shaping associated communities across spatial scales remain to be elucidated.

\section{Acknowledgements}

We would like to thank F Gentil, C Broudin and G Abidbol for help with animal identification, and M-L Ciriani for help with biomass analyses. We are particularly grateful to the marine operations staff at the Roscoff Biological Station (Service Mer \& Observation SBR), especially Y Fontana, W Thomas, M Camusat \& N Guidal for help with fieldwork. We thank T. de Bettignies and T. Wernberg for irradiance data. Comments by A Grémare, K Kovalenko, tow anonymous reviewers and English edits by $\mathrm{C}$ Engel-Gautier substantially improved the manuscript. This work benefited from the support of the Brittany Regional Council and the French National Research Agency via the 'Investment for the Future' programme IDEALG (no. ANR-10-BTBR-04).

\section{Electronic supplementary material}

Below is the link to the electronic supplementary material.

Supplementary material 1 Incident light (Lux, raw data and third order moving average) monitored every $15 \mathrm{~min}$ within a kelp-cleared plot (3 $\mathrm{m}$ diameter) between April, 14th and June, 19th 2014 on the study site using onset HOBO data loggers Pendant Temp-Light, Onset Computer Corporation. Courtesy of Thibaut de Bettignies and Thomas Wernberg. *: Tidal range $>6.5 \mathrm{~m}$ (JPEG $541 \mathrm{~kb})$ 
Supplementary material 2 Macroalgae identified during the survey across the different strata (Lamina, Stipe, Holdfast and Rock). Relative occurrence in samples is indicated: $\mathrm{x}$ : 1-6 samples, $\mathrm{xx}$ : 7-13 samples, $\mathrm{xxx}$ : 14-20 samples. ${ }^{\circ}$ : species identified underwater by scuba-divers (XLSX $15 \mathrm{~kb}$ )

Supplementary material 3 Sessile macrofauna identified during the survey across the different strata (Lamina, Stipe, Holdfast and Rock). Relative occurrence in samples is indicated: $x$ : 1-6 samples, $x x$ : 7-13 samples, $x x x$ : 14-20 samples. ${ }^{\circ}$ : species identified underwater by scuba-divers (XLSX $16 \mathrm{~kb}$ )

Supplementary material 4 Mobile macrofauna identified during the survey across the different strata (Lamina/Stipe, Holdfast and Rock). Relative occurrence in samples is indicated: $x$ : 1-6 samples, $x x$ : 7-13 samples, $x x x$ : 14-20 samples. ${ }^{\circ}$ : species identified underwater by scuba-divers (XLSX $23 \mathrm{~kb}$ )

Supplementary material 5 Results of SIMPER analyses of Bray-Curtis similarity among consecutive sampling dates for biomass abundance of seaweeds associated with the different kelp forest strata. Seaweed average abundances $(\mathrm{Ab}$.) were square-root-transformed. Relative contributions of species to the dissimilarity $\left({ }^{-} j \%\right)$ between consecutive sampling dates are presented depending on PERMANOVA results. Values in bold: Species abundances and contribution to dissimilarity for species found in the cut-off levels of 50\% in pairwise comparisons. Phy (Phyllum): Och: Ochrophyta, Chl: Chlorophyta, Rho: Rhodophyta. (XLSX $13 \mathrm{~kb}$ )

Supplementary material 6 Results of SIMPER analyses of Bray-Curtis similarity among consecutive sampling dates for biomass abundance of sessile fauna associated with the different kelp forest strata. Fauna average abundances (Ab.) were square-root-transformed. Relative contributions of species to the dissimilarity $\left({ }^{-} j \%\right)$ between consecutive sampling dates are presented depending on PERMANOVA results. Values in bold: Species abundances and contribution to dissimilarity for species found in the cut-off levels of $50 \%$ in pairwise comparisons. Phy (Phylum): Por: Porifera, Bry: Bryozoa, Cho: Chordata (XLSX $13 \mathrm{~kb}$ ) 
Supplementary material 7 Results of SIMPER analyses of Bray-Curtis similarity among consecutive sampling dates for numerical abundance of mobile fauna associated with the different kelp forest strata. Fauna average abundances (Ab.) were square-root-transformed. Relative contributions of species to the dissimilarity $\left({ }^{-} j \%\right)$ between consecutive sampling dates are presented depending on PERMANOVA results. Values in bold: Species abundances and contribution to dissimilarity for species found in the cut-off levels of $50 \%$ in pairwise comparisons. Phy (Phylum): Ann: Annelida, Mol: Mollusca, Art: Arthropoda, Ech: Echinodermata, Sip: Sipunculida. TG (Trophic group): G: Grazer, DF: Deposit-feeder, SF: Suspension-feeder, sf-P: sessile fauna-Predator, mf-P: mobile fauna-Predator (XLSX $20 \mathrm{~kb}$ )

\section{References}

Airoldi, L., 2003. The effects of sedimentation on rocky coast assemblages. Oceanography and Marine Biology: An Annual Review 41: 161-236.

Altieri, A. H. \& J. Van de Koppel, 2014. Foundation species in marine ecosystems. In Bertness, M. D., J. F. Bruno, B. R. Silliman \& J. J. Stachowicz (eds), Marine Community Ecology and Conservation. Sinauer Associates Inc, Sunderland, MA: 37-56.

Anderson, M. J., 2001. A new method for non-parametric multivariate analysis of variance. Austral Ecology 26: 32-46.

Anderson, M. J., C. E. Diebel, W. M. Blom \& T. J. Landers, 2005. Consistency and variation in kelp holdfast assemblages: spatial patterns of biodiversity for the major phyla at different taxonomic resolutions. Journal of Experimental Marine Biology and Ecology 320: 35-56.

Anderson, M. J., R. N. Gorley \& K. R. Clarke, 2008. PERMANOVA+ for PRIMER: Guide to Software and Statistical Methods. PRIMER-E, Plymouth.

Arzel, P., 1998. Les laminaires sur les côtes bretonnes: Evolution de l'exploitation de la flottille de pêche, état actuel et perspectives, Ifremer ed. Ifremer, Plouzané. 
Azzarello, J. J., D. A. Smale, T. J. Langlois \& E. Håkansson, 2014. Linking habitat characteristics to abundance patterns of canopy-forming macroalgae and sea urchins in southwest Australia. Marine Biology Research 10: 682-693.

Bedford, A. P. \& P. G. Moore, 1985. Macrofaunal involvement in the sublittoral decay of kelp debris: the polychaete Platynereis dumerilii (Audouin and Milne-Edwards) (Annelida: Polychaeta). Estuarine, Coastal and Shelf Science 20: 117-134.

Bekkby, T., E. Rinde, H. Gundersen, K. M. Norderhaug, J. K. Gitmark \& H. Christie, 2014. Length, strength and water flow: Relative importance of wave and current exposure on morphology in kelp Laminaria hyperborea. Marine Ecology Progress Series 506: 61-70.

Bell, J. J., M. Burton, B. Bullimore, P. B. Newman \& K. Lock, 2006. Morphological monitoring of subtidal sponge assemblages. Marine Ecology Progress Series 311: 79-91.

Bennett, S., T. Wernberg, T. de Bettignies, G. A. Kendrick, R. J. Anderson, J. J. Bolton, K. L. Rodgers, N. T. Shears, J.-C. Leclerc, L. Lévêque, D. Davoult \& H. C. Christie, 2015. Canopy interactions and physical stress gradients in subtidal communities. Ecology Letters 18: 677-686.

Birrien, J. L., M. V. M. Wafar, P. L. Corre \& R. Riso, 1991. Nutrients and primary production in a shallow stratified ecosystem in the Iroise Sea. Journal of Plankton Research 13: 721-742.

Bruno, J. F. \& M. D. Bertness, 2001. Habitat modification and facilitation in benthic marine communities. In Bertness, M. D., S. D. Gaines \& M. E. Hay (eds), Marine Community Ecology. Sinauer Associates Inc., Sunderland, MA: 201-218.

Buschbaum, C., S. Dittmann, J.-S. Hong, I.-S. Hwang, M. Strasser, M. Thiel, N. Valdivia, S.-P. Yoon \& K. Reise, 2009. Mytilid mussels: global habitat engineers in coastal sediments. Helgoland Marine Research 63: $47-58$.

Cárdenas, C. A., S. K. Davy \& J. J. Bell, 2015. Influence of canopyforming algae on temperate sponge assemblages. Journal of the Marine 
Biological Association of the United Kingdom: 1-12.

Castilla, J. C., R. Guiñez, A. U. Caro \& V. Ortiz, 2004. Invasion of a rocky intertidal shore by the tunicate Pyura praeputialis in the Bay of Antofagasta, Chile. Proceedings of the National Academy of Sciences of the United States of America 101: 8517-8524.

Chapman, M. G. \& A. J. Underwood, 1996. Experiments on effects of sampling biota under intertidal and shallow subtidal boulders. Journal of Experimental Marine Biology and Ecology 207: 103-126.

Christie, H., S. Fredriksen \& E. Rinde, 1998. Regrowth of kelp and colonization of epiphyte and fauna community after kelp trawling at the coast of Norway. Hydrobiologia 375-376: 49-58.

Christie, H., N. M. Jørgensen, K. M. Norderhaug \& E. Waage-Nielsen, 2003. Species distribution and habitat exploitation of fauna associated with kelp (Laminaria hyperborea) along the Norwegian coast. Journal of the Marine Biological Association of the United Kingdom 83: 687-699.

Christie, H., N. M. Jørgensen \& K. M. Norderhaug, 2007. Bushy or smooth, high or low; importance of habitat architecture and vertical position for distribution of fauna on kelp. Journal of Sea Research 58: 198-208.

Christie, H., K. M. Norderhaug \& S. Fredriksen, 2009. Macrophytes as habitat for fauna. Marine Ecology Progress Series 396: 221-233.

Clarke, K. R. \& M. Ainsworth, 1993. A method of linking multivariate community structure to environmental variables. Marine Ecology Progress Series 92: 205-219.

Clarke, K. R. \& R. M. Warwick, 2001. Change in Marine Communities: An Approach to Statistical and Interpretation, 2nd ed. PRIMER-E, Plymouth.

Clarke, K. R., P. J. Somerfield \& M. G. Chapman, 2006. On resemblance measures for ecological studies, including taxonomic dissimilarities and a zero-adjusted Bray-Curtis coefficient for denuded assemblages. Journal of Experimental Marine Biology and Ecology 330: 55-80. 
Coma, R., M. Ribes, J.-M. Gili \& M. Zabala, 2000. Seasonality in coastal benthic ecosystems. Trends in Ecology \& Evolution 15: 448-453.

Connell, S. D., 2003. Negative effects overpower the positive of kelp to exclude invertebrates from the understorey community. Oecologia 137: 97-103.

Connell, S. D., 2005. Assembly and maintenance of subtidal habitat heterogeneity: synergistic effects of light penetration and sedimentation. Marine Ecology Progress Series 289: 53-61.

Connell, S., M. Foster \& L. Airoldi, 2014. What are algal turfs? Towards a better description of turfs. Marine Ecology Progress Series 495: 299-307.

Crisp, D. J., 1984. Energy flow measurements. In Holme, N. A. \& A. D. McIntyre (eds), Methods for the Study of Marine Benthos. Blackwell, Oxford: 197-279.

Dean, R. L. \& J. H. Connell, 1987a. Marine invertebrates in an algal succession. I. Variations in abundance and diversity with succession. Journal of Experimental Marine Biology and Ecology 109: 195-215.

Dean, R. L. \& J. H. Connell, 1987b. Marine invertebrates in an algal succession. III. Mechanisms linking habitat complexity with diversity. Journal of Experimental Marine Biology and Ecology 109: 249-273.

Downes, B. J., P. Lake, E. Schreiber \& A. Glaister, 1998. Habitat structure and regulation of local species diversity in a stony, upland stream. Ecological Monographs 68: 237-257.

Dubois, S., C. Retière \& F. Olivier, 2002. Biodiversity associated with Sabellaria alveolata (Polychaeta: Sabellariidae) reefs: effects of human disturbances. Journal of the Marine Biological Association of the United Kingdom 82: 817-826.

Duggins, D. O., J. E. Eckman, C. E. Siddon \& T. Klinger, 2003. Population, morphometric and biomechanical studies of three understory kelps along a hydrodynamic gradient. Marine Ecology Progress Series 265: 57-76. 
Gee, J. M. \& R. M. Warwick, 1994. Body-size distribution in a marine metazoan community and the fractal dimensions of macroalgae. Journal of Experimental Marine Biology and Ecology 178: 247-259.

Gibbons, M. J., 1988. The impact of sediment accumulations, relative habitat complexity and elevation on rocky shore meiofauna. Journal of Experimental Marine Biology and Ecology 122: 225-241.

Graham, M. H., 2004. Effects of local deforestation on the diversity and structure of southern California giant kelp forest food webs. Ecosystems 7: 341-357.

Graham, A. \& V. Fretter, 1947. The life history of Patina pellucida (L.). Journal of the Marine Biological Association of the United Kingdom 26: 590-601.

Greene, C. H. \& A. Schoener, 1982. Succession on marine hard substrata: a fixed lottery. Oecologia 55: 289-297.

Hacker, S. D. \& R. S. Steneck, 1990. Habitat architecture and the abundance and body-size-dependent habitat selection of a phytal amphipod. Ecology 71(6): 2269-2285.

Hay, M. E., 1981. The functional morphology of turf-forming seaweeds: persistence in stressful marine habitats. Ecology 62: 739-750.

Hily, C. \& F. Jean, 1997. Macrobenthic biodiversity in intertidal habitats of the Iroise bioshere reserve (Brittany, France). Journal of the Marine Biological Association of the United Kingdom 77: 311-323.

Jones, D. J., 1971. Ecological studies on macroinvertebrates associated with polluted kelp forests in the North Sea. Helgolander Wissenschaftliche Meeresuntersuchungen 22: 417-441.

Jones, D. J., 1973. Variation in the trophic structure and species composition of some invertebrate communities in polluted kelp forest in the North Sea. Marine Biology 20: 351-365.

Jørgensen, N. M. \& H. Christie, 2003. Diurnal, horizontal and vertical dispersal of kelp-associated fauna. Hydrobiologia 503: 69-76. 
Joubin, L., 1909. Recherche sur la distribution océanographique des végétaux marins dans la région de Roscoff. Annales de 1'Institut océanlogique de Monaco, vol. 1.

Kain, J. M., 1963. Aspects of the Biology of Laminaria hyperborea II. Age, weight and length. Journal of the Marine Biological Association of the United Kingdom 43: 129-151.

Kain, J. M., 1971. The Biology of Laminaria hyperborea VI. Some Norvegian populations. Journal of the Marine Biological Association of the United Kingdom 51: 387-408.

Kain, J. M., 1976a. The Biology of Laminaria hyperborea IX. Growth Pattern of Fronds. Journal of the Marine Biological Association of the United Kingdom 56: 603-628.

Kain, J. M., 1976b. The Biology of Laminaria hyperborea VIII. Growth on cleared areas. Journal of the Marine Biological Association of the United Kingdom 56: 267-290.

Kain, J. M., 1982. The reproductive phenology of nine species of Rhodophyta in the subtidal region of the Isle of Man. British Phycological Journal 17: 321-331.

Kelaher, B. P., 2002. Influence of physical characteristics of coralline turf on associated macrofaunal assemblages. Marine Ecology Progress Series 232: $141-148$.

Kendrick, G. A., P. S. Lavery \& J. C. Phillips, 1999. Influence of Ecklonia radiata kelp canopy on structure of macro-algal assemblages in Marmion Lagoon, Western Australia. Hydrobiologia 398-399: 275-283.

Kovalenko, K. E., S. M. Thomaz \& D. M. Warfe, 2012. Habitat complexity: approaches and future directions. Hydrobiologia 685: 1-17.

Leclerc, J.-C., P. Riera, C. Leroux, L. Lévêque \& D. Davoult, 2013. Temporal variation in organic matter supply in kelp forests: linking structure to trophic functioning. Marine Ecology Progress Series 494: 87-105. 
Leclerc, J.-C., P. Riera, M. Laurans, C. Leroux, L. Lévêque \& D. Davoult, 2015. Community, trophic structure and functioning in two contrasting Laminaria hyperborea forests. Estuarine, Coastal and Shelf Science 152: $11-22$.

Lee, J. T., J. Widdows, M. B. Jones \& R. A. Coleman, 2004. Settlement of megalopae and early juveniles of the velvet swimming crab Necora puber (Decapoda: Portunidae) in flow conditions. Marine Ecology Progress Series 272: 191-202.

Littler, M. M. \& D. S. Littler, 1984. Relationships between macroalgal functional form groups and substrata stability in a subtropical rockyintertidal system. Journal of Experimental Marine Biology and Ecology 74: $13-34$.

Littler, M. M., D. R. Martz \& D. S. Littler, 1983. Effects of recurrent sand deposition on rocky intertidal organisms: importance of substrate heterogeneity in a fluctuating environment. Marine Ecology Progress Series 11: 129-139.

Lůning, K., 1986. New frond formation in Laminaria hyperborea (Phaeophyta): a photoperiodic response. British Phycological Journal 21: 269-273.

MacArthur, R. H. \& J. W. MacArthur, 1961. On bird species diversity. Ecology 42: 594-598.

Maldonado, M., K. Giraud \& C. Carmona, 2008. Effects of sediment on the survival of asexually produced sponge recruits. Marine Biology 154: 631-641.

Martin-Smith, K. M., 1993. Abundance of mobile epifauna: the role of habitat complexity and predation by fishes. Journal of Experimental Marine Biology and Ecology 174: 243-260.

McCormick, M. I., 1994. Comparison of field methods for measuring surface topography and their associations with a tropical reef fish assemblages. Marine Ecology Progress Series 112: 87-96.

McGuinness, K. A. \& A. J. Underwood, 1986. Habitat structure and the 
nature of communities on intertidal boulders. Journal of Experimental Marine Biology and Ecology 104: 97-123.

McQuaid, C. \& K. Dower, 1990. Enhancement of habitat heterogeneity and species richness on rocky shores inundated by sand. Oecologia 84 : $142-144$.

Miller, R. J. \& H. M. Page, 2012. Kelp as a trophic resource for marine suspension feeders: a review of isotope-based evidence. Marine Biology 159: 1391-1402.

Miller-Rushing, A. J., T. T. Høye, D. W. Inouye \& E. Post, 2010. The effects of phenological mismatches on demography. Philosophical Transactions of the Royal Society B: Biological Sciences 365: 3177-3186.

Moore, P. G., 1973. The Kelp fauna of Northeast Britain. II. Multivariate classification: turbidity as an ecological factor. Journal of Experimental Marine Biology and Ecology 13: 127-163.

Morlon, H., E. P. White, R. S. Etienne, J. L. Green, A. Ostling, D. Alonso, B. J. Enquist, F. He, A. Hurlbert, A. E. Magurran, B. A. Maurer, B. J. McGill, H. Olff, D. Storch \& T. Zillio, 2009. Taking species abundance distributions beyond individuals. Ecology Letters 12: 488-501.

Murray, S. N., R. F. Ambrose \& M. N. Dethier, 2006. Monitoring Rocky Shores. University of California Press, Berkeley, CA.

Norderhaug, K. M., 2004. Use of red algae as hosts by kelp-associated amphipods. Marine Biology 144: 225-230.

Norderhaug, K. M., H. Christie \& E. Rinde, 2002. Colonisation of kelp imitations by epiphyte and holdfast fauna; a study of mobility patterns. Marine Biology 141: 965-973.

Norderhaug, K. M., H. Christie, J. H. Fossa \& S. Fredriksen, 2005. Fish-macrofauna interactions in a kelp (Laminaria hyperborea) forest. Journal of the Marine Biological Association of the United Kingdom 85: 1279-1286.

Norderhaug, K. M., H. Christie \& S. Fredriksen, 2007. Is habitat size an 
important factor for faunal abundances on kelp (Laminaria hyperborea)? Journal of Sea Research 58: 120-124.

Norderhaug, K. M., H. Christie, E. Rinde, H. Gundersen \& T. Bekkby, 2014. Importance of wave and current exposure to fauna communities in Laminaria hyperborea kelp forests. Marine Ecology Progress Series 502: 295-301.

Norton, T. A., K. Hiscock \& J. A. Kitching, 1977. The ecology of Lough Ine: XX. The Laminaria forest at Carrigathorna. Journal of Ecology 65: 919-941.

Ockelmann, K. W. \& C. Nielsen, 1981. On the biology of the prosobranch Lacuna Parva in the Øresund. Ophelia 20: 1-16.

Paul, V. J., R. Ritson-Williams \& K. Sharp, 2011. Marine chemical ecology in benthic environments. Natural Product Reports 28: 345-387.

Prathep, A., R. H. Marrs \& T. A. Norton, 2003. Spatial and temporal variations in sediment accumulation in an algal turf and their impact on associated fauna. Marine Biology 142: 381-390.

Rasmussen, E., 1973. Systematics and Ecology of the Isefjord Marine Fauna (Denmark). Ophelia 11: 1-507.

Reed, D. C. \& M. S. Foster, 1984. The effects of canopy shading on algal recruitment and growth in a giant kelp forest. Ecology 65: 937-948.

Rinde, E. \& K. Sjøtun, 2005. Demographic variation in the kelp Laminaria hyperborea along a latitudinal gradient. Marine Biology 146: 1051-1062.

Schaal, G., P. Riera \& C. Leroux, 2009. Trophic significance of the kelp Laminaria digitata (Lamour.) for the associated food web: a between-sites comparison. Estuarine, Coastal and Shelf Science 85: 565-572.

Schaal, G., J.-C. Leclerc, G. Droual, C. Leroux \& P. Riera, 2016.

Biodiversity and trophic structure of invertebrate assemblages associated with understory red algae in a Laminaria digitata bed. Marine Biology Research. doi:10.1080/17451000.2016.1164318. 
Schultze, K., K. Janke, A. Krüss \& W. Weidemann, 1990. The macrofauna and macroflora associated with Laminaria digitata and L. hyperborea at the island of Helgoland (German Bight, North Sea). Helgolander Wissenschaftliche Meeresuntersuchungen 44: 39-51.

Seed, R. \& R. J. O’Connor, 1981. Community organization in marine algal epifaunas. Annual Review of Ecology and Systematics 12: 49-74.

Smale, D. A., M. T. Burrows, P. Moore, N. O'Connor \& S. J. Hawkins, 2013. Threats and knowledge gaps for ecosystem services provided by kelp forests: a northeast Atlantic perspective. Ecology and Evolution 3: 4016-4038.

Sournia, A. \& J. L. Birrien, 1995. La série océanographique côtière de Roscoff (Manche occidentale) de 1985 à 1992. Cahiers de Biologie Marine 36: $1-8$.

Thrush, S. F., M. Chiantore, V. Asnagi, J. Hewitt, D. Fiorentino \& R. Cattaneo-Vietti, 2011. Habitat-diversity relationships in rocky shore algal turf infaunal communities. Marine Ecology Progress Series 424: 119-132.

Tokeshi, M. \& S. Arakaki, 2012. Habitat complexity in aquatic systems: fractals and beyond. Hydrobiologia 685: 27-47.

Toth, G. B. \& H. Pavia, 2002. Lack of phlorotannin induction in the kelp Laminaria hyperborea in response to grazing by two gastropod herbivores. Marine Biology 140: 403-409.

Waage-Nielsen, E., H. Christie \& E. Rinde, 2003. Short-term dispersal of kelp fauna to cleared (kelp-harvested) areas. Hydrobiologia 503: 77-91.

Wafar, M. V. M., P. Le Corre \& J. L. Birrien, 1983. Nutrients and primary production in permanently well-mixed temperate coastal waters. Estuarine, Coastal and Shelf Science 17: 431-446.

Wernberg, T. \& N. Goldberg, 2008. Short-term dynamics of algal species in a subtidal kelp bed in relation to changes in environmental conditions and canopy biomass. Estuarine, Coastal and Shelf Science 76: 265-272.

Whittick, A., 1983. Spatial and temporal distributions of dominant 
epiphytes on the stipes of Laminaria hyperborea (Gunn.) Fosl.

(Phaeophyta: Laminariales) in S.E. Scotland. Journal of Experimental Marine Biology and Ecology 73: 1-10.

Wulff, J. L., 2006. Ecological interactions of marine sponges. Canadian Journal of Zoology 84: 146-166. 